\title{
Unconventional Monetary Policy and Long-Term Interest Rates
}


Unconventional Monetary Policy and Long-Term Interest Rates

Tao $W u$ 


\title{
IMF Working Paper
}

IMF Institute for Capacity Development

\section{Unconventional Monetary Policy and Long-Term Interest Rates \\ Prepared by Tao $\mathrm{Wu}^{1}$}

Authorized for distribution by Laura Ellen Kodres

September 2014

\section{This Working Paper should not be reported as representing the views of the IMF.} The views expressed in this Working Paper are those of the author(s) and do not necessarily represent those of the IMF or IMF policy. Working Papers describe research in progress by the author(s) and are published to elicit comments and to further debate.

\begin{abstract}
This paper examines the transmission mechanism through which unconventional monetary policy affects long-term interest rates. I construct a real-time measure summarizing market projections of the magnitude and duration of the Federal Reserve's Large Scale Asset Purchases (LSAP) program, and analyze the determination of term premiums and expectations of future short-term interest rates in a sample spanning more than two decades. Empirical findings suggest that the LSAP has effectively lowered the long-term Treasury bond yields, through both "signaling" and "portfolio balance" channels. On the other hand, the Fed's "forward guidance" also leads to gradual extension of market projections for the duration of the LSAP program, thereby enhancing the LSAP's effect to keep term premiums low. Estimation results also reveal a diminished effectiveness of the LSAP during QE III. Finally, model simulations underscore the importance of policy transparency in minimizing unnecessary market turbulence and ensuring a timely and smooth exit of the unconventional monetary policy stimulus.
\end{abstract}

JEL Classification Numbers: E43; E44; E52; E58; G12

Keywords: Unconventional monetary policy, Quantitative easing, Large-scale asset purchases, Long-term interest rates, Signaling effect, Portfolio balance, Tapering, Exit strategy

Author’s E-Mail Address: twu@imf.org

\footnotetext{
${ }^{1}$ I thank Roberto Cardarelli, Andy Levin, Rebecca McCaughrin, and Gian Maria Milesi-Ferretti for helpful comments.
} 


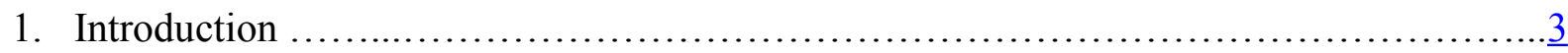

2. A Real-Time Measure of the Federal Reserve's LSAP Program............................

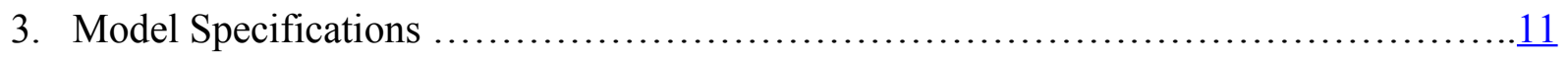

4. Portfolio Balance Channel: The UMP and Term Premiums ...........................14

5. Signaling Channel: The UMP and Short-Rate Expectations ...........................20

6. The "Tapering" Myth and the "Exit" of UMP .......................................

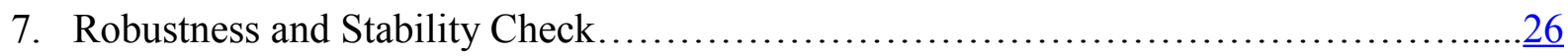

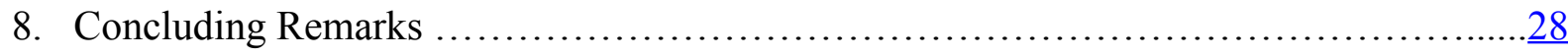

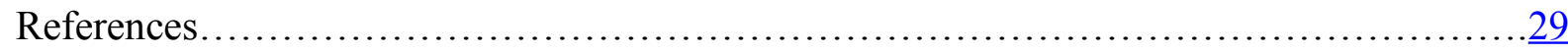

Technical Appendix: Construction of the Real-Time LSAP Measures .......................44

Tables

1. Determination of Ten-Year Term Premium ........................................

2. Decomposition of Changes in Ten-Year Term Premium: September 2008 to May

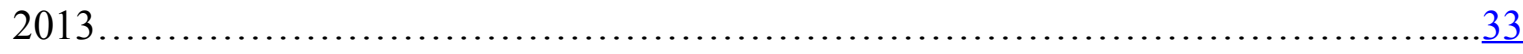

3. Effects of LSAP and "Forward Guidance" on Ten-Year Term Premium...................34

4. Determination of the Average of Expected Future Short Rates ....................... $\underline{36}$

5. Determination of the Average of Expected Future Short Rates: Alternative $L S A P^{N}$

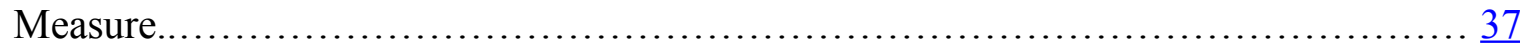

6. Determination of Ten-Year Term Premium: Robustness Check.................... $\underline{38}$

7. Decomposition of Changes in Ten-Year Term Premium: September 2008 to May 2013, Alternative Bond Yield Decompositions ........................................ $\underline{39}$

8. Determination of the Average of Expected Future Short Rates: Robustness Check...... $\underline{40}$

Figures

1. Evolution of Market-Projected Path of Excess SOMA Holding........................

2. Present Discounted Value of Market's Projected SOMA Balance........................

3. Ten-year Treasury Bond Yield and Term Premium Estimates...........................42

4. Real-time and Counter-Factual LSAP Measures...........................................................42

5. Simulations of Ten-Year Term Premium.......................................... 43 


\section{Introduction}

After the short-term interest rate becomes constrained by the zero lower bound (ZLB), a central bank may still be able to affect the aggregate demand, as real activity such as consumption and investment are largely dependent upon long-term borrowing costs or interest rates, which the central bank can still influence. As any long-term interest rate can be decomposed into an expectations component which equals the average of expected future short-term interest rates, and a term premium component, the central bank can aim at lowering either component, or both, to achieve its goal. This so-called unconventional monetary policy (UMP) is the type of policy that central banks in several advanced economies including the United States, the United Kingdom, and Japan, have been conducting during the most recent financial crisis after their short-term policy rates had essentially hit the ZLB.

For instance, in the United States, the unconventional monetary policy measures conducted by the Federal Reserve since late 2008 can be described as follows: on the one hand, the FOMC has been trying to guide the market expectations of future short-term interest rates, by first announcing that the federal funds rate would remain at "exceptionally low levels" for "some time" (FOMC statement on January 28, 2009) and later "an extended period" (on March 18, 2009), followed by a switch to a more specific calendar date of "at least through mid-2013" (on August 9, 2011), and further extending the date to "at least through late 2014" (on January 25, 2012 ) and then again "at least through mid-2015" (on September 13, 2012). Finally, the FOMC changed the guidance format from the date-based approach to a threshold-based approach, linking the "lift-off" or the first increase of the federal funds target rate to specific economic indicators such as the unemployment rate and inflation expectations. Such "forward guidance" practices clearly reflect a continuing effort to lower the market expectations of future short-term interest rates and thus the expectations component of long-term interest rates.

On the other hand, after the financial market was stabilized by early 2009 and the Federal Reserve began to withdraw from its temporary liquidity injection facilities such as the term auction facility (Wu 2011), the Federal Reserve initiated a Large Scale Asset Purchase (LSAP) program, under which the Federal Reserve has cumulatively purchased about $\$ 4$ trillion's worth of long-term Treasury securities and Mortgage-backed securities (MBS), and is still continuing such purchases. This program, usually referred to as quantitative easing (QE), is clearly not aiming at further stabilizing financial market as the market conditions had been largely stabilized 
by early 2009, but rather, aiming at lowering the term premium component of long-term interest rates through affecting the supply-demand balance on the bond market. The Federal Reserve has apparently hoped that the combined efforts of "forward guidance" and the LSAP would help lower the long-term Treasury bond yields and mortgage rates, and that the reduction in Treasury bond yields would then spill over to other long-term interest rates and other sectors of the economy; and consequently, lower borrowing costs, as well as a positive wealth effect that is usually associated with such declines in long-term interest rates, would eventually stimulate aggregate demand and real activity.

Therefore, the effectiveness of the UMP depends entirely on how well this transmission channel works, in particular, on the first step - how the long-term interest rates react to the Fed's "forward guidance" and "quantitative easing." Among the two types of policy measures, the evaluation of forward guidance is relatively straightforward, since the market has been pricing the near-future short-term interest rates in a way that is to a great extent consistent with the FOMC's interest rate projections, as data from the federal funds futures market, Eurodollar futures market, and various surveys have suggested. However, ambiguity remains on the effectiveness of the Fed's LSAP program on lowering the long-term interest rates, in particular, the term premiums.

Recent studies have generally agreed that such large-scale purchases of QE assets have helped to reduce the long-term interest rates. Among many others, Bauer and Rudebusch (2013), D'Amico and King (2013), Gagnon et al. (2011), Hamilton and Wu (2012), Krishnamurthy and Vissing-Jorgensen (2011), Neely (2012), and Woodford (2012). The International Monetary Fund report (2013a) provides a comprehensive literature survey. However, the estimated magnitude of such effects differs greatly (International Monetary Fund, 2013a). More importantly, the channels through which such asset purchases may affect the long rates remain unclear. So far, literature has explored two possible channels for the LSAP to affect long-term interest rates: one is a "portfolio balance" channel due to market segmentation (Joyce et al., 2011) or duration removal (Gagnon et al., 2011), through which central bank purchases of specific bonds might affect the risk pricing and term premiums of the purchased bonds and a wide range of securities; and the other, a "signaling" channel, which suggests that such purchases may signal to market participants that the central bank has changed either its views on the economic outlook or its policy preference, and bond investors therefore change their expectations of the future 
path of the policy rate accordingly, thereby lowering the expectations component of the longterm bond yields and thus the long-term bond yields (Bauer and Rudebusch 2013). Yet the relative effectiveness of these channels remains "a matter of considerable debate" (Woodford 2012). For instance, Woodford (2012) notes that "a comparison of the timing of the increases in the Fed's holdings of long term bonds with the timing of the declines in the 10-year yield does not obviously support a portfolio-balance interpretation of the overall decline in long-term interest rates," whereas some other researchers such as Gagnon et al. (2011) are skeptical about signaling effect and suggest that the portfolio balance channel explains most of the observed declines in long-term bond yields.

The interaction between the "forward guidance" and the LSAP is another intriguing issue. On the one hand, changes in the LSAP program may indicate changes in the FOMC's assessment of the underlying economic conditions and thus may also generate changes in the market's expectations of the future short-term policy rate. On the other hand, changes in the FOMC's "forward guidance" policy such as extensions of the calendar dates to keep the federal funds rate around zero should have also affected the market's expectation of the size and persistence of the LSAP program, for instance when or how soon the "exit" or unloading of the LSAP assets may take place. Thus a later "lift-off" date for the federal funds rate should also help to reduce the term premiums, in addition to its effect in lowering the future short rate path. Yet so far such interactions between the "forward guidance" and the LSAP have not been thoroughly and quantitatively analyzed in the literature.

This paper aims to examine the transmission channels linking unconventional monetary policy to affect long-term interest rates. To measure the magnitude of the LSAP program and facilitate a quantitative assessment of the effectiveness of such purchases, I first construct an indicator summarizing the market expectations of the size and duration of the LSAP program, based on real-time policy announcements as well as market surveys. I then separately analyze the effectiveness of the "forward guidance" and the LSAP in affecting term premiums and the expected future short rates, after controlling for changes in underlying macroeconomic and financial market fundamentals. This approach enables me to quantitatively separate the effects of pure "forward guidance" announcements from those of the LSAP per se. It also allows me to closely examine how changes in market expectations of future UMP, in particular the Fed's "exit strategy," may lead to immediate and substantial market reactions, as have been observed 
in recent months.

Estimation results suggest that the Federal Reserve's "forward guidance" and the LSAP policies have effectively lowered the long-term bond yields and term premiums during the most recent crisis, lowering the 10-year term premium by more than 100 basis points. In particular, in addition to the conventional view that "forward guidance" alters the public's expectation of future short rates and thus the expectations component of long-term interest rates, and that LSAPs lower the term premiums, there is strong evidence suggesting two spillover effects: on the one hand, "forward guidance" also leads to a gradual extension of market's projected length of the holding period of the LSAP assets, thereby enhancing the LSAP's effect to keep term premiums low; on the other hand, the continuing LSAPs also help to enhance the credibility of the "forward guidance" and guide the market's expectations of future short-term interest rates.

The rest of the paper is organized as follows. Section 2 describes the methodology in constructing the real-time measure of the Fed's LSAP policy, and Section 3 discusses the model specifications for the later empirical analysis. Section 4 examines the effects of the Fed's "forward guidance" and LSAP policies in affecting the term premiums, and Section 5 analyzes these two policies' effects in guiding market expectations of future short-term interest rates. Section 6 takes a closer look at the recent market movement since mid-2013 and discusses potential challenges that the Federal Reserve faces as they decide to exit the UMP. Section 7 reports the results of a robustness and stability check. Section 8 concludes.

\section{A Real-Time Measure of the Federal Reserve's LSAP Pro- gram}

When a central bank expands its balance sheet through purchases of financial securities, two key policy parameters are needed to clearly define such a policy action: the size of such purchases, and the length of time that the purchased portfolio will stay on the central bank's balance sheet. A central bank may choose to clearly specify and commit to both parameters, or keep one or

both parameters at its discretion and instead communicate with the public about its policy intention on an on-going basis. Market participants will then formulate their expectations of the unspecified policy parameters, based on policy announcements as well as their projections of the underlying macroeconomic and financial conditions. Other related parameters, such as

CInternational Monetary Fund. Not for Redistribution 
the type of securities to be purchased, or those pertaining to the operational side of the policy actions, for instance, the speed of such purchases, are usually clearly announced beforehand in order to minimize possible disruptions to financial markets.

Thus the strength of such policies essentially depends on both key parameters: the size of the purchases and the length of holding period of the purchased assets. A larger purchase or a longer holding period will generate a larger portfolio rebalance effect if financial assets are not perfect substitutes (Tobin 1961, Joyce et al. 2011), or the purchase results in a shorter remaining duration (Gagnon et al. 2011), or is interpreted as a stronger signal for the future policy stance to be accommodative (Woodford 2012), all leading to larger market responses. Therefore, a useful measure of such policies needs to incorporate information on both dimensions of the policy.

In this section I construct a quantitative measure based on the market's expectations of the future path of the Federal Reserve's balance sheet, following Chung, Laforte, Reifschneider, and Williams (2012). Specifically, at any given point in time, in particular following each major policy announcement from the FOMC or each major revision to the economic outlook since late 2008, I trace the market participants' projections of the future path of the Federal Reserve's SOMA (System Open Market Account) balance using survey data, and calculate the present discounted value of the current and future balance (excluding holdings of short-term Treasury securities) as a ratio to potential GDP, in excess of the historical normal level of the ratio. Changes of this real-time measure then capture the variations of market's expectations of the size or persistence of the LSAP program over time, and the measure itself becomes a valid proxy of the strength of the relevant QE policies.

Since late 2008 the Federal Reserve has implemented four rounds of Quantitative Easing through the LSAP program: QE I (November 2008 to March 2010), QE II (November 2010 to June 2011), Operation Twist (September 2011 to December 2012), and QE III (since September 2012 and still ongoing). However, the Federal Reserve has never explicitly specified the length of the holding period of these LSAP assets, i.e., when the Fed will begin to unload these assets from its balance sheet or how long this process may take, leaving much of it for market speculation. Even the intended purchase amount is sometimes not pre-announced or pre-set. For instance, as of today, QE III remains an open-end purchase program, ${ }^{1}$ and speculations on when the FOMC

\footnotetext{
${ }^{1}$ For instance, in his congressional testimony on July 17, 2013, the Federal Reserve Chairman Ben Bernanke made the following remarks on the QE III purchases "...asset purchases depend on economic and financial developments, they are by no means on a preset course."
}

CInternational Monetary Fund. Not for Redistribution 
may decide to reduce or "taper" the monthly pace of the QE III purchases have generated substantial uncertainty in the markets since late May 2013. Given such policy uncertainty, it becomes particularly challenging but vitally important to identify the market's expectations of the Fed's QE policy going forward.

Surveys of market participants prove to be a very useful reference in this aspect. To quantify how the market's expectations of future LSAP policy have evolved over time, I incorporate market information from various sources, in particular the Survey of Primary Dealers compiled by the Federal Reserve Bank of New York. Prior to each FOMC meeting, the New York Fed's Market Group conducts a survey among their primary dealers. ${ }^{2}$ The survey questions are based "on topics widely discussed in public, including in FOMC statements, meeting minutes, and remarks by FOMC members. FOMC members are not consulted in the formulation of survey questions." The survey "helps the FOMC to evaluate what the market is anticipating in terms of the outlook for the economy, monetary policy, and financial markets." ${ }^{3}$ The survey results, in particular the survey respondents' expectations of the future size of the SOMA balances, when combined with the policy announcements from the FOMC as well as the FOMC communications with the market (including both the FOMC members' public speeches and their economic projections published periodically), help to derive the market participants' real-time projections of the Fed's LSAP program. Further details of the construction of the LSAP measure are included in the technical appendix at the end of the paper.

Figure 1 displays the evolution of the market-projected path of the excess SOMA balance in real time, starting on November 25, 2008 when the Federal Reserve made the initial LSAP announcement that it would purchase up to $\$ 100$ billion in agency debt and up to $\$ 500$ billion in agency Mortgage Backed Securities (MBS). The QE I phase of the LSAP eventually saw the Fed buying $\$ 1.25$ trillion of MBS, $\$ 300$ billion of longer-term Treasury securities, and $\$ 175$ billion of agency debt, raising the total excess SOMA balance to almost 11 percent of the U.S. potential GDP by the end of 2009. Moreover, market participants had generally expected that the Fed would gradually renormalize the size and composition of its balance sheet, bringing the

\footnotetext{
${ }^{2}$ The Federal Reserve's primary dealers consist of large commercial banks and securities brokers and dealers who serve as trading counterparties of the Federal Reserve Bank of New York in its implementation of monetary policy on behalf of the Federal Reserve. The current complete list of primary dealers can be found at http://www.newyorkfed.org/markets/pridealers_current.html.

${ }^{3}$ http://www.newyorkfed.org/markets/primarydealer_survey_questions.html
} 
excess SOMA holdings back to zero by early 2016 (Chung, Laforte, Reifschneider, and Williams 2012). The QE II phase of the LSAP program, with an additional purchase of $\$ 600$ billion of longer-term Treasury securities, brought the excess-SOMA-holdings-to-potential-GDP ratio to 14 percent, and also caused the market to speculate that the Fed's balance sheet would return to normal at a later date.

"Operation Twist" did not aim at increasing the size of the Fed's balance sheet per se. Rather, "[T]he Committee intends to purchase, by the end of June 2012, $\$ 400$ billion of Treasury securities with remaining maturities of 6 years to 30 years and to sell an equal amount of Treasury securities with remaining maturities of 3 years or less" (FOMC statement, September 21, 2011). However, it still increased the SOMA's holdings of longer-term Treasury securities, to a level equivalent to more than 16 percent of the U.S. potential GDP as of August 2012. "Operation Twist" continued throughout the end of 2012, although at the same time the FOMC also initiated a fourth phase of the LSAP program, the so-called "QE III," by first announcing on September 13, 2012 of its plan to purchase "additional agency mortgage-backed securities at a pace of $\$ 40$ billion per month," and later (December 12, 2012) an additional $\$ 45$ billion per month of longer-term Treasury securities. As of September 2013, the QE III remained an active purchase program at the pace of $\$ 85$ billion per month, and market participants generally believe that the purchasing pace will be gradually reduced to zero around mid-2014 (Bernanke September 18, 2013), implying a peak amount of almost 23 percent of the U.S. potential GDP for the excess SOMA balance in the first half of 2014 .

Once the real-time market projections of future path of excessive SOMA balance are imputed, the next step is to calculate the present discounted value of these projections at each point in time. The resulted series are displayed in Figure 2. By construction, this forward-looking measure not only captures the current size of the Fed's balance sheet, but more importantly, also incorporates the market's view of the Fed's future LSAP policy, for instance, how soon the FOMC is going to start "tapering" its QE III purchases, or when and how fast the FOMC may begin to sell off these purchased assets and exit from the current "highly accommodative" policy stance. Therefore, it will be used as a quantitative measure of the strength of the Fed's LSAP program in the later econometric analysis of long-term bond yields and term premiums.

This measure also helps to shed light on the different transmission channels through which the "forward guidance" policy and the LSAP policy take effect. On the one hand, with a 
quantitative measure of the LSAP policy, one can now separately analyze the effects of the LSAP policy on the expectations and term premium components of long-term interest rates, thereby evaluate the relative importance of the LSAP's "signaling" effect and "portfolio balance" effect. A recent study by Bauer and Rudebusch (2013) have taken a model-free, event study approach and found substantial changes of expectations of future short rates on key QE I announcement days. By conducting a more structural time-series analysis in an updated sample of more than two decades, this study should provide more insight into this issue.

In addition, the constructed LSAP measure also helps to examine the effect of "forward guidance" policy announcements on the term premiums, an important aspect of the UMP that is largely ignored in the literature so far. A "forward guidance" announcement of a later federal funds rate "lift-off" not only will lower the market projection of future short-rate path and thus the expectations component of long-term interest rates, but may also cause the market participants to speculate on a later "exit" for the LSAP program, and thereby upwardly revise their projections of future path of the SOMA balance. In particular, the FOMC explicitly announced an exit strategy for unwinding the LSAP, clearly stating that it intends to first "modify its forward guidance on the path of the federal funds rate" and "begin raising its target for the federal funds rate," and that the "sales of agency securities from the SOMA will likely commence sometime after the first increase in the target for the federal funds rate." (FOMC meeting minutes, June 22, 2011). Therefore, as soon as the FOMC extends its guidance on how long the federal funds rate would be kept close to zero, investors would also revise their expectations of the LSAP unwinding schedule as well as the entire future path of the SOMA balance accordingly. Consequently, this "forward guidance" announcement may also generate a portfolio balance effect leading to a decline in the term premiums.

For instance, on January 25, 2012, the FOMC extended its guidance on the schedule of maintaining the near-zero federal funds rate from "at least through mid-2013" to "at least through late 2014." Even though there were no explicit changes to the LSAP program on that day, the fact that the first short-rate hike or "lift-off" was postponed for more than a year could have led the markets to speculate on a similar delay of the LSAP unwinding schedule. Indeed this is reflected by an upward shift of the projected path of excessive SOMA balance in Figure 1, as well as the increases in the presented discounted value of the projected path in Figure 2. Therefore, this "forward guidance" announcement appears to have affected both the 
expectation component and the term premium component of long-term bond yields. As it turns out, the 10-year Treasury bond yield declined by 17 basis points on the announcement day and the following day, reflecting a 12-basis point decline in term premium and 5 basis points decline in the average of expected future short-term interest rates.

\section{Model Specifications}

The yield to maturity of a $\tau$-period zero-coupon bond in period $t$ can be decomposed into the sum of an expectations component and a term premium component:

$$
i_{\tau t}=\frac{1}{\tau} \sum_{k=0}^{\tau-1} E_{t} i_{1, t+k}+t p_{\tau t}
$$

where $E_{t} i_{1, t+k}$ is the one-period interest rate from period $t+k$ to $t+k+1$ as expected in period $t$,

and $\frac{1}{\tau} \sum_{k=0}^{\tau-1} E_{t} i_{1, t+k}$ the average of the expected future short rates over the next $\tau$ periods. From a macroeconomic perspective, the one-period or short rate is determined by a central bank as a primary tool of monetary policy in response to changes in current and expected macroeconomic and financial conditions which are summarized in a state vector $X_{t}$

$$
i_{1, t}=f\left(X_{t}\right)
$$

Term premium $t p_{\tau t}$ depends on both the price per unit of risk and the $\tau$-period bond's loadings of the risk, both of which also depend on the state vector $X_{t}$. Under an affine structure in which the price of risk is a linear function of the underlying state vector $X_{t}$ which itself follows a Gaussian process, both the bond yield and term premium can be expressed as linear functions of the underlying state variables

$$
\begin{gathered}
i_{\tau t}=A_{\tau}+B_{\tau} X_{t} \\
t p_{\tau t}=A_{\tau}^{t p}+B_{\tau}^{t p} X_{t}
\end{gathered}
$$

And it follows that the expectations component of the bond yields, which is identical to the average of expected future short rates, is also a linear function of the state vector $X_{t}$. Details of deriving such an affine term structure can be found in the canonical term structure literature such as Duffie and Kan (1996) and the macro-finance literature including Ang and Piazzesi (2003), Wu (2006), and Rudebusch and Wu (2008).

This section builds an econometric model to examine the determination of bond yields and term premiums, with the model specification guided by the affine term structure model above. It 
explores the statistical relationship between the bond yields and a set of variables that are closely associated with movement of bond yields and term premiums, following the methodology in $\mathrm{Wu}$ (2011). To capture variations in the underlying macroeconomic and financial fundamentals, the following variables are included:

\section{Macroeconomic fundamentals:}

a. Unemployment rate gap, measured by the difference between the unemployment rate and the U.S. Congressional Budget Office's estimates of potential unemployment rate;

b. Consumer confidence, measured by the expectations component of Conference Board's Consumer Confidence index;

c. Long-run inflation expectation, measured by the ten-year-ahead CPI inflation forecast from Survey of Professional Forecasters (SPF);

d. Short-run inflation expectation, measured by one-year-ahead inflation expectation from Reuters/University of Michigan Surveys of Consumers;

e. Short-run actual inflation, measured by twelve-month changes in the core PCE price index;

\section{Macroeconomic uncertainties:}

f. Growth uncertainty, measured by the forecast dispersion among the SPF respondents on four-quarter-ahead real GDP;

g. Labor market uncertainty, measured by the forecast dispersion among the SPF respondents on four-quarter-ahead unemployment rate;

h. Inflation uncertainty, measured by the forecast dispersion among the SPF respondents on four-quarter-ahead inflation of GDP deflator;

\section{Financial market volatilities:}

i. The implied volatility in the longer-term U.S. Treasury market, measured by Merrill Lynch MOVE index;

j. The uncertainty in the stock market, measured by the VIX index of implied volatility from options on S\&P 500 index;

k. The uncertainty regarding the near-term path of monetary policy rate, measured by the implied volatility from six-month-ahead Eurodollar futures options.

\section{The LSAP measure}


1. The constructed real-time measure of the present discounted value of the projections of the Federal Reserve's excessive SOMA holdings under the LSAP program (the solid black line in Figure 2).

The following regression is conducted to examine the determination of Treasury bond yields and the different components of the yields:

$$
i_{t}=\varphi+X_{I t} \beta_{I}+X_{I I t} \beta_{I I}+X_{I I t} \beta_{I I I}+L S A P_{t} \beta_{L S A P}+\varepsilon_{t}
$$

where $X_{I t}, X_{I I t}$, and $X_{I I I t}$ denote vectors of variables on macroeconomic fundamentals, macroeconomic uncertainties, and financial market volatilities as listed above, and $L S A P_{t}$ denotes the constructed LSAP measure. $\beta$ 's are the associated coefficients, and $\varphi$ the intercept. The dependent variable $i_{t}$ represents the term premium component or the expectations component of the ten-year Treasury bond yield.

Data on Treasury bond yields are readily available through many data sources including the Federal Reserve Board's website. ${ }^{4}$ However, data on the term premium component and the expectations component of the yields are not directly available, as the former depends on the pricing of interest rate risks and the latter on the average of expected future short-term interest rates, both unobservable. Certain model-based restrictions on the price and structure of the underlying risks must be imposed to decompose the yields into these two components. In the later econometric analysis, I use the Kim-Wright decomposition as published by the Federal Reserve Board (Kim and Wright 2005, denoted as KW henceforth) to examine the effectiveness of unconventional monetary policy on bond yields. Of course, different term structure model specifications will lead to different decompositions of the bond yields and potentially different quantitative results, and for robustness I also adopt two other widely used model-based decompositions in the empirical analysis: D'Amico, Kim, and Wei (2010, DKW henceforth), and Adrian, Crump and Moench (2012, ACM henceforth). As shown in Section 7, results obtained under the three different decompositions are mostly consistent with each other.

The estimation sample uses monthly data from January 1992 to September 2013, a total of 261 months. As shown in Figure 3, this period includes the gradual disinflation and the continued declines of long-term bond yields in the 1990s and 2000s, which is characterized by many as a period of "Great Moderation," as well as the turbulent period of financial crisis

\footnotetext{
${ }^{4}$ http://www.federalreserve.gov/pubs/feds/2006/200628/200628abs.html
} 
or "Great Recession" since late 2007 and the associated unconventional monetary policies. In the later econometric analysis, this full sample period will be split into different sub-sample periods to test the stability of estimation results, for instance, a pre-crisis sample from January 1992 to August 2008, right before the failure of Lehman Brothers and AIG, and a crisis sample from September 2008 to the present. Different sample periods will also be used to examine the robustness of the obtained conclusions.

\section{Portfolio Balance Channel: The UMP and Term Premiums}

I first run model (5) to examine the evolution of term premiums in the past two decades. As Table 1 indicates, the model fits the data well, with an $R^{2}$ of 85 to 90 percent. In particular, the fullsample and pre-crisis sample estimation results (first two columns of Table 1) suggest that term premiums tend to be counter-cyclical even though the coefficient estimates of unemployment rate gap are not statistically significant. This is consistent with the conventional view that investors tend to be more risk-averse during economic downturns. On the other hand, term premiums are very sensitive to changes in long-run inflation expectations, as one percentage point increase in 10-year-ahead CPI inflation expectation will generate a 1.26 percentage point rise in 10-year term premium, and such changes are statistically significant at one percent level. However, term premiums are much less sensitive to changes in short-run inflation expectations or realized inflation in the past 12 months, suggesting that market participants tend to believe that these short-run inflation variations may dissipate and have very limited effects on the long-run inflation outlook.

The crisis sample estimation (column 3 of Table 1) reveals a slightly different pattern. On the one hand, term premium responses to changes in unemployment rate gap become more substantial and much more significant (at the one percent level), consistent with the central role that labor market conditions have played in the Federal Reserve's unconventional monetary policy decision-making during the most recent crisis. On the other hand, the coefficient estimate of the 10-year-ahead CPI inflation expectation loses its statistical significance, most likely resulting from a much shorter sample period and a lack of variations of long-run inflation expectation during this period (always between 2.2 percent and 2.5 percent). However, term premiums become more sensitive to changes in short-run inflation and inflation outlook, as investors become immensely attuned to speculation on the Federal Reserve's policy actions during 
the crisis period, and the short-run inflation outlook now has a heavier weight in affecting the market's long-run projections than pre-crisis.

Responses of the term premium to macroeconomic uncertainties are stable across different sample periods. In particular, heightened uncertainties on real growth and unemployment rate tend to increase the term premium, and such responses are statistically significant at the one percent level. The response of the term premium to inflation uncertainty is statistically insignificant in pre-crisis sample, but becomes statistically significant during the crisis period. A careful examination of the data reveals that, despite a general disinflation in the past two decades in the United States, this measure of inflation uncertainty has not declined, and had indeed risen modestly during 2009-2011, when the Fed began to aggressively implement monetary loosening and term premiums declined substantially. Because of the short crisis-sample period (5 years), the negative coefficient estimate may simply reflect this particular episode rather than a long-lasting statistical relationship.

Coefficient estimates of financial market volatilities are also stable across different sample periods and consistent with general intuition. A rise in the implied volatility of longer-term bond market tends to increase the term premiums, and the response is significant at one percent level. The coefficient estimate on the VIX measure of implied volatility of stock market is slightly negative and statistically insignificant, probably reflecting a "flight to quality" effect: When the stock market becomes more volatile, investors would adjust their portfolio and increase the weights of the less risky Treasury bonds, and consequently bond prices tend to rise and term premiums and bond yields tend to decline. Finally, the 10-year term premium responses to changes in near-term short-rate volatility are neither substantial nor statistically significant during either pre-crisis or crisis sample periods, suggesting that uncertainty about the near-term policy rate has little effect on long-term interest risk pricing.

More importantly, estimation results in Table 1 also reveal a substantial effect of the Fed's LSAP program in lowering the term premiums. Note that the constructed LSAP measure calculates the present discounted value of the projected excess-SOMA-balance-to-potential-GDP ratio, therefore by construction a 100 percentage point increase in the $L S A P$ measure is equivalent to an immediate increase of the SOMA balance in the amount of 20 percent of nominal potential GDP (about $\$ 3.4$ trillion as of 2013), and the purchased assets are projected to stay on the Fed's balance sheet for about five years before immediately disappearing. According to 
column 1 of Table 1 , such a purchase would reduce the 10 -year term premium by 1.12 percentage points, and this effect is statistically significant at the one percent level. Results based on the much shorter crisis-period sample imply a smaller effect, about 0.62 percentage point, yet the coefficient estimate remains significant at the one percent level.

Combined with the constructed $L S A P$ measure (Figure 2), the estimated $L S A P$ coefficient value provides a quantitative assessment of the effects of different phases of the Fed's unconventional monetary policy on term premiums. For instance, between September 2008 and May 2013, the 10-year Treasury bond yield had declined by 217 basis points, more than half of which is due to decline in the 10-year term premium (114 basis points according to the KW decomposition as published at the Federal Reserve Board's website). A decomposition of the changes in the 10-year term premium over this period provides insights into the driving forces behind the observed declines.

As shown in Table 2, changes in macroeconomic fundamentals from the peak of the financial crisis in September 2008 to May 2013 increased the 10-year term premium by 26 basis points, largely reflecting a sluggish recovery in labor market conditions as the unemployment rate remained 1.5 percentage points higher than in September 2008; declines in macroeconomic uncertainties had helped to lower the term premium by 19 basis points, and a similar magnitude of decline is attributable to the improvement in financial market stability. Changes in the constructed $L S A P$ measure alone had reduced the term premium by 113 basis points, indicating a substantial and persistent effect of the Federal Reserve's unconventional monetary policy during this period. Specifically, changes in the $L S A P$ measure have helped reduce the term premium by 35 basis points in the QE I phase (November 2008 to March 2010), 9 basis points in QE II (September 2011 to August 2012), and 19 and 26 basis points in the "Operation Twist" (September 2011 to August 2012) and QE III phases (September 2012 to May 2013), respectively.

Two points need to be clarified here. First, an LSAP announcement will immediately generate an upward revision to the market's projections of the future SOMA balance path and thus an increase in the $L S A P$ measure. ${ }^{5}$ However, without any further actions, this measure tends to

\footnotetext{
${ }^{5}$ Here I assume that the LSAP purchases affect bond yields and term premiums primarily through stock effects, i.e., "persistent changes in prices that result from movements along Treasury demand curves," rather than flow effects ("response of prices to the ongoing purchase operations" due to "sluggish price discovery" (D'Amico and King, forthcoming). As these two authors find out, the majority of bond yield responses to the $\$ 300$ billion
} 
gradually decline over time, as the market anticipates the LSAP program to gradually approach its termination. Therefore, to maintain the same amount of policy stimulus, the Fed needs to either conduct new purchases, or signal an extension of the length of time that the purchased assets will stay on its balance sheet.

Second and more importantly, in the current policy setting, the LSAP policy and the "forward guidance" policy on short-term interest rates are intimately intertwined. As explained in Section 2, a "forward guidance" announcement of a later federal funds rate "lift-off" not only will lower the market projection of future short-rate path and thus the expectations component of long-term interest rates, but may also cause the market participants to speculate on a later "exit" of the LSAP program, and thereby generate an upward revision to their projected path of future SOMA balance and the $L S A P$ measure. For instance, the Federal Reserve did not conduct any active LSAP-related bond purchases after QE II was completed by the end of the second quarter of 2011 and before the beginning of "Operation Twist" in September 2011. However, in early August 2011, a pure FOMC announcement of its intention to keep the federal funds rate at exceptionally low levels "at least through mid-2013" caused market participants to anticipate a later unloading of the LSAP assets that the Fed had already purchased, and resulted in a 20 basis point decline in the 10-year term premium according to the model estimate. Similarly, the occasional "forward guidance" during the periods with active bond purchases, either through explicit FOMC announcements or less explicit methods of market communications, should have also changed the market's expectations of the persistence of the LSAP program along with the on-going purchases and thus the constructed LSAP measure and term premiums. Therefore, the quantitative figures reported in Table 2 for different QE phases should be interpreted as the combined effects of both LSAP and "forward guidance" on term premiums, rather than the effect of the LSAP per se.

In an effort to isolate these two effects, the following experiment is conducted: For each round of the LSAP, assuming that market participants never change their expectation of the length of holding period of the assets that the Fed has already purchased, i.e., the effect of a later "forward guidance" is not retrospective and can only affect market projections of the holding period of asset purchases going forward, I can construct a counter-factual $L S A P^{N}$ measure that is arguably unaffected by the "forward guidance" announcements, and the difference between Treasury purchases during QE I in 2009 were due to stock effects (50 basis points) rather than flow effects (3 to 4 basis points).

CInternational Monetary Fund. Not for Redistribution 
these two LSAP measures captures the influences of "forward guidance" in extending the holding period of purchased LSAP assets and thereby lowering the term premiums (Figure 4). ${ }^{6}$ The newly constructed $L S A P^{N}$ measure, which aims to capture the pure effect of LSAP per se, is then fed into the regression model (5), along with its difference from the original $L S A P$ measure which captures the "forward guidance"-related component of the $L S A P$ measure.

The decomposition of $L S A P$ measure reveals that a substantial part of the LSAP-related policy stimulus since early 2010 is related to the "forward guidance" policy. For instance, at the height of the constructed LSAP measure at 104 percent of GDP in early 2013 (Figure 4), over 45 percentage points come from gradual extensions of length of the holding period of LSAP assets (the difference between the two lines in Figure 4), which is primarily affected by "forward guidance." Model estimation (Table 3) also suggests that a substantial part of the decline in term premiums result from "forward guidance"-related changes in the $L S A P$ measure, and the associated coefficient estimate is statistically significant at the one percent level. According to the estimates (column 1 in Table 3), the initial effect of the $\$ 1.725$ trillion QE I purchases per se was to reduce the 10-year term premium by 45 basis points in early 2009, and such effect tends to dissipate over time. However, as the market successively projects a later date for these assets to be sold off, their effect become even more intensified over time. For instance, as of early 2013, the market participants generally believed that most of these QE I assets would be kept on the Fed's balance sheet at least through early 2016 before the unloading process begins, which is five to six years later than what they used to believe in 2009. This extension of the projected "exit" date for $\mathrm{QE}$ I assets alone has contributed almost 40 percentage points to the $L S A P$ reading in early 2013, and has implied a 34-basis point reduction in 10-year term premium as of early 2013.

In the model estimation (Table 3) I also allow for the effectiveness of LSAP policy to change over time, by introducing dummy variables on different phases of the LSAP program (QE I, QE II, Operation Twist, and QE III). Many, including some FOMC members, have suspected that

\footnotetext{
${ }^{6}$ Of course, "forward guidance" and the LSAP program are so intimately related to each other that there is not an approach to clearly separate their effects. For instance, one may also argue that, in deciding the magnitude of QE II purchases, the FOMC might have already taken into account the "forward guidance" and changes in market expectations of the length of holding period of QE I assets after the completion of QE I purchases, and thus the $L S A P^{N}$ measure of QE II only captures part of the stimulus that the FOMC intended to provide through LSAP by then, so that the estimated effect is a lower bound of the LSAP effect in QE II.
}

CInternational Monetary Fund. Not for Redistribution 
the effects of the LSAP policy have declined over time whereas others have different views, ${ }^{7}$ yet there has been little empirical evidence to verify or refute this argument. Therefore, two related exercises are conducted in Table 3: I first allow for the effects of pure purchases $\left(L S A P^{N}\right)$ to differ over time, and next I allow for the effects of "forward guidance"-related term (LSAP $\left.L S A P^{N}\right)$ to change over time.

Estimation results reveal substantial variations in the LSAP effect across different QE phases, in particular for QE III, as the estimated coefficient for the QE III dummy is only about onethird of that of other QE dummies in the first exercise and slightly more than half in the second exercise. Moreover, such differences are statistically significant: in both exercises, the likelihood ratio test suggests that the null hypothesis of all dummies being identical to zero can be rejected at the one percent significance level, but the null hypothesis that dummies on the first three QE phases are equal and are jointly different from the dummy on QE III cannot be rejected at any commonly used significance level ( $p$-value is greater than 25 percent in both cases). Thus, it seems that the LSAP effect has been effectively unchanged during the first three phases of the QE, but has been significantly reduced during the on-going QE III phase.

In summary, empirical analysis of term premiums in this section implies the following: First, the LSAP program since late 2008 has been effective in reducing term premiums, by more than 100 basis points as of mid-2013; secondly, both the pure bond purchases and a gradual extension of the length of holding period of the purchased assets as projected by market have contributed substantially to the declines in term premiums, and in the current policy setting, the latter factor is closely related to the Fed's "forward guidance" policy; and finally, the effectiveness of LSAP and "forward guidance" in lowering the term premium exhibits substantial variations over time, in particular, the effects become much weaker during the QE III phase, and such differences are statistically significant.

\footnotetext{
${ }^{7}$ Even opinions among the FOMC members seem to be divided. For instance, according to published minutes of the March 20, 2013 FOMC meeting, some FOMC members "expressed the view that these effects had likely been stronger during the Federal Reserve's initial large-scale asset purchases ... Other participants, however, saw little evidence that the efficacy of asset purchases had declined over time, and a couple of these suggested that the effectiveness of purchases might even have increased more recently."
}

CInternational Monetary Fund. Not for Redistribution 


\section{Signaling Channel: The UMP and Short-Rate Expectations}

Next I turn to analyze the determination of the expectations of future short-term interest rates. Specifications of the empirical analysis here are motivated by the following observation: if a central bank's "forward guidance" can help market participants formulate a clear projection of the future short rate path with full commitment, the expectations component of long-term bond yields, which is identical to the average of expected future short rates over the maturity of the bond, should not be affected by any other policies including the LSAP, as the short-rate projection itself is sufficient to derive the average expected future short rates. However, in reality, and in particular under the current policy environment in the United States, there exist several discrepancies that invalidate this strong proposition. First, there has been tremendous uncertainties on the macroeconomic and financial fundamentals in the past as well as going forward, and this prevents the Federal Reserve from being able to make explicit and solid promises on its future policy-rate path with perfect foresight. Second, the format of the Fed's "forward guidance" does not enable the market to infer a complete path for future short rates. For instance, the current exercise of linking the federal funds rate "lift-off" to some threshold level of certain economic indicators such as unemployment rate at 6.5 percent is not a guarantee that the federal funds rate will be changed once the threshold is reached. Indeed, Chairman Bernanke and other FOMC members made it very clear that such levels are "thresholds" rather than "triggers." Moreover, the "forward guidance" communications so far have conveyed little information on the short-rate path after the first rate "lift-off," leaving much of it for markets to speculate on. Finally, the policy preference and assessment of economic outlook even among the FOMC members are quite diverse, as reflected in their different views as published in the FOMC meeting minutes and the wide margin of their economic projections. ${ }^{8}$ Therefore, the continuing LSAP may have not only kept the term premiums down, but also helped enhance the credibility of the Fed's "forward guidance" and maintain the projected future short-term interest rates at a low level.

\footnotetext{
${ }^{8}$ For instance, the FOMC statement on September 13, 2012 indicates that the committee "currently anticipates that exceptionally low levels for the federal funds rate are likely to be warranted at least through mid-2015." However, the simultaneously published "FOMC Participants' Assessments of Appropriate Monetary Policy" reveals that at least 6 of the 19 FOMC participants would like to raise the federal funds rate by the end of 2014 . Undoubtedly, this has generated uncertainties regarding the future path of short-term interest rates and more generally, the Fed's exit strategy.
}

CInternational Monetary Fund. Not for Redistribution 
To evaluate this effect, I replace the dependent variable $i_{t}$ in equation (5) by the expectations component of 10-year Treasury bond yield and run the same regression. Note that as long as the current and future short-term interest rates are determined by the central bank in response to changes in the underlying state variables $X_{t}^{\prime} \mathrm{s}$, equation (5) remains a valid specification, and the $L S A P$ coefficient estimates help to gauge the influences of LSAP policy on the future short-rate projections, which are the primary focus of the Fed's "forward guidance" policy. ${ }^{9}$

Estimation results (Table 4) are consistent with the intuition that the average of expected future short rates is strongly pro-cyclical, and rises when the unemployment rate gap diminishes, or consumer confidence becomes stronger. It also reacts very strongly whenever long-run or short-run inflation expectation edges up. However, response of the average future short rates to changes in macroeconomic uncertainties is mild, and its correlations with volatility measures on financial market are also much smaller than the ones reported in Table 1 for term premiums, consistent with the general view that short-term interest rates are primarily used as a tool to counter business cycles rather than one to improve financial stability. However, whenever there is a heightened uncertainty on near-future short-term interest rates (such as 6-month Eurodollar volatility), the average expected short rates tend to decline and the coefficient estimates are significant at the one percent level, revealing that short-term Eurodollar rate could influence the FOMC's weight on financial stability.

Of particular interest is the coefficient estimate of the $L S A P$ measure. As reported in Table 4 , this coefficient estimate is negative and statistically significant at one percent level, suggesting a substantial and negative effect of the LSAP on market projections of the future short-term interest rates. Indeed, a decomposition of the 107-basis point decline in the average of expected future short rates from September 2008 to May 2013, conducted in a similar fashion as in Table 2, suggests that only 25 basis points can be attributed to changes in macroeconomic fundamentals during this period; the effects of changes in macroeconomic uncertainties and financial market uncertainties are relatively small and almost cancel out each other; and changes in the $L S A P$ measure contribute 84 basis points to the total decline. This indicates the significance of the

\footnotetext{
${ }^{9}$ One may argue that when the short-term interest rate becomes bounded by zero, the short rate process, if previously dictated by a simple Taylor rule, becomes non-linear, and the projection of future short rates may not be linear any more. However, even after the short rate hits the zero bound, the average of expected future short rate (e.g., over the next ten years) remains well above zero (Figure 3), and as long as a central bank aims at lowering the projected future short rate path, equation (5) should still be a valid specification.
}

CInternational Monetary Fund. Not for Redistribution 
signaling channel for the LSAP to affect expectations of future short rates and thus long-term interest rates, in addition to its effect through portfolio balance channel to lower the term premiums.

As discussed in the last section, the constructed $L S A P$ measure incorporates information from "forward guidance," and thus the estimate obtained above may be an over-estimate of the LSAP's signaling effect on future short rates. To isolate the pure signaling effect of the LSAP per se on future short-term interest rates, I replace the $L S A P$ measure by the constructed $L S A P^{N}$ measure and re-examine its effect. As Table 5 reveals, the new coefficient estimate of $L S A P^{N}$ is only slightly smaller than that of $L S A P$ and remains statistically significant, and the implied changes in $L S A P^{N}$ still account for at least 45 basis points in the 107-basis point decline of the average future short rate (coefficient estimate of -0.0076 in column 1 of Table 5 times an $L S A P^{N}$ reading of 59 percent). This suggests that the LSAP has effectively enhanced the Fed's "forward guidance" policy in keeping the projected future short-rate path low. ${ }^{10}$

Overall, the empirical analysis reveals a complicated transmission mechanism for the "forward guidance" and LSAP policies to affect long-term interest rates. In addition to the direct channels through which the "forward guidance" and the LSAP affect the market's projection of the future short-rate path and the term premiums, respectively, there are additional spillover effects: "forward guidance" also leads to a gradual extension of market's projected length of the holding period of the LSAP assets, thereby generating a far more persistent effect for the LSAP; on the other hand, the continuance of LSAPs also helps to enhance the credibility of the "forward guidance" and guide the market's expectations of future short-term interest rates, thus generating a signaling effect. In short, these two types of policies are intimately intertwined, supporting each other in lowering both the term premiums and public's expectation of future short-term interest rates.

\footnotetext{
${ }^{10}$ The estimates presented here are very close to those obtained in other studies. For instance, the implied "signaling" effect of QE I purchases on the average expected future short rates over the next ten years is 27 basis points (based on estimates in Table 4) or 30 basis points (based on estimates in Table 5). In their event study, Bauer and Rudebusch (2013) aggregate the daily changes in their estimates of expected future short rates on all key QE I announcement days and obtain a cumulative "signalling" effect between zero and 60 basis points for different maturity horizons. They do not report a "signaling" effect for the average expected future short rate over next ten years, but from their Figure 2, such an average would be very close to 30 basis points, almost identical to the implied estimates here.
}

CInternational Monetary Fund. Not for Redistribution 


\section{The "Tapering" Myth and the "Exit" of UMP}

Since December 2012, the FOMC has entered another phase of its LSAP program, generally referred to as "QE III." This on-going phase differs from the previous ones in that the current QE III is an open-end bond purchasing program, i.e., the FOMC only announces its intention to purchase $\$ 85$ billion of long-term Treasury and other securities each month but not the termination date of such purchases, leaving the "tapering," i.e., when the FOMC will begin to slow the monthly purchasing pace and how soon such purchases will end, for market speculation.

The market turns out to be much more sensitive to news on "tapering" than many had anticipated. For instance, the 10-year Treasury yield jumped by about 100 basis points in a few weeks after mid-May 2013, in particular around the June 19 FOMC meeting. The abrupt rise in long-term interest rates surprised both the market and policy makers. As Fed Chairman Bernanke admitted on his June 19, 2013 press conference, "we were a little puzzled by that. It was bigger than can be explained I think by changes in the ultimate stock of asset purchases within reasonable ranges..." (Bernanke, June 19 2013). And long-term interest rates rose even more rapidly after that press conference.

Market participants have generally attributed this turbulence to uncertainty on the "tapering" of the QE III purchases, which seems puzzling, as an earlier "tapering" only moderates the bond purchasing pace but still increases the total stock of LSAP assets, therefore the monetary policy stance remains highly expansionary. In other words, a reduction in the new purchases is not the beginning of a sell-off in the LSAP assets, as it still increases the size of the Fed's balance sheet. Moreover, even if the market participants had expected an earlier "tapering" than before, changes in the projected purchase amount would be modest: for instance, if the market had expected that the FOMC would start "tapering" in September 2013 instead of December 2013, the total amount of the QE III purchases will only differ by at most $\$ 150$ billion. Compared to the over $\$ 3.6$ trillion LSAP assets that the Fed had already purchased by then, revisions of such a magnitude seem too small to generate a sizable disturbance.

One possible explanation of this myth is that market participants may have assumed a high correlation among different pieces of the FOMC's unconventional monetary policy: the "tapering" of the on-going QE III purchases, the "forward guidance" on when the federal funds rate may "lift off," and the timing of the beginning of the withdrawal of the LSAP assets (the "exit"). In particular, given the substantial uncertainties in the economy, the FOMC is simply 
unable to elaborate with perfect foresight any of these policy measures, neither on the "tapering" nor the "exit strategy." As Bernanke states, "asset purchases are not on a preset course. The Committee's decisions about their pace will remain contingent on the economic outlook and on the Committee's ongoing assessment of the likely efficacy and costs of the program" (Bernanke, September 18, 2013). Consequently, market participants' speculations regarding all these policy measures are linked, and whenever there is any news on one policy measure, they will also try to infer the FOMC's evaluation of the economic outlook and speculate on the other policy measures.

Therefore, when the market participants speculated on an earlier "tapering" in mid-2013, it is quite likely that they also revised their projections of the federal funds rate "lift-off," as well as the unloading schedule of the LSAP assets. Indeed, various surveys have suggested that market participants substantially changed their projections of the federal funds rate "lift-off" date, moving it forward from the third quarter of 2015 to the first quarter of 2015. This means that in addition to changes in the projected "tapering" amount, two related events may have also occurred: an upward shift of the future short rate path which leads to a rise in the expectations component of long-term bond yields, and a downward shift of the future SOMA balance path which contributes to an increase in term premiums. Both lead to an increase in long-term bond yields.

A quantitative analysis helps to evaluate the magnitude of such effects, first on the changes of the average of future short rates. If we assume that the federal funds rate will rise steadily after its "lift-off" to its long-run (pre-crisis) average level of 4 to 4.5 percent, and that the slope of this projected path (i.e., the speed at which the federal funds rate will be increased after the "lift-off") remains unchanged, a two-quarter earlier "lift-off" will generate a 20 to 25 basis point increase in the average of expected short rate over the next ten years. And in the case where market participants might have also upwardly revised their projections of the speed of the rate increases after the "lift-off," this figure would be even larger.

Next we look at the effect of the market's speculation on an earlier "tapering" on the changes in term premiums. According to the FOMC's "exit principle" as publicly announced in June 2011, the unloading schedule of the LSAP assets is to be closely tied to that of "forward guidance." Thus it is reasonable to assume that if the market projects an earlier federal funds rate "lift-off" by two quarters, then its projection of the future path of SOMA balance will also be 
revised accordingly. For illustration, Figure 5 displays results from a hypothetical experiment: assume that all the underlying fundamental and volatility measures in model equation (5) are projected to return to their long-run (pre-crisis) average levels over a three-year period beginning in June 2013, model estimates in Table 1 and the projected $L S A P$ path in Figure 2 generate a smooth path for the projected term premiums over the next few years as of May 2013, with the model predicted value for May 2013 very close to the actual value.

The solid black line in Figure 5 plots the model-implied 10-year term premium path as of June 2013, assuming that the market participants now anticipate a two-quarter earlier "exit" of the LSAP program (holding other fundamentals unchanged). The 10-year term premium rises to -22 basis points, almost identical to the actual reading of -24 basis points. Of the 48 -basis point term premium increase as observed in the month, 18 basis points are attributable to strengthening in consumer confidence, another 18 basis points to heightened bond-market volatility as reflected in the MOVE index, and 12 basis points to the changes in market's projection of future SOMA path. Thus the majority of the observed rise in long-term bond yields in June 2013 seem to reflect market's perceptions of an earlier "lift-off" date, an earlier "exit" process of the LSAP program, a strengthening in consumer confidence, and an increase of bond-market volatility.

As the FOMC gradually concludes QE III and approaches the "exit" of unconventional monetary policy, similar market turbulence may occur again, because under the current environment it is very difficult for market expectations of future monetary policy to be firmly anchored, due to heightened uncertainty in the economy, the desire for the FOMC to keep future policy largely at its discretion, and a general unfamiliarity of the unconventional monetary policy. For instance, market participants may speculate on not only when the "exit" may begin, but also how fast the LSAP assets may be sold off and the Fed's balance sheet size may return to its normal level. For example, in June 2013, if market participants had also projected a faster "exit" process that it takes three years instead of five years for the Fed's balance sheet to return to normal the 10-year term premium would have increased by another 17 basis points (Figure 5). Moreover, if the heightened uncertainty had generated a "rush to exit" effect (International Monetary Fund 2013b), as reflected in an increase in the elasticity of term premiums to changes in the $L S A P$ measure, for instance, by one standard deviation, the 10-year term premium would have jumped by another 13 basis points. All such shocks may be very persistent throughout the "exit" process, and thereby pose potential challenges to policy makers in designing and executing a 
smooth withdrawal of the unconventional monetary policy stimulus.

These simulations underscore the importance of enhancing policy communications with the public and successfully guiding market expectations of the FOMC's future policy during the "exit" process, including the policy format, procedures, and the criteria and principles behind specific policy actions. Improved policy transparency will not only help de-link the correlations between "tapering" and the "exit strategy" and thus ease market jitters in the short run, but also help improve the efficiency of the monetary policy transmission mechanism and ensure a timely and smooth exit going forward.

\section{Robustness and Stability Check}

A number of robustness and stability checks are conducted to verify the validity of the main conclusions. First I estimate the model using alternative definitions of the underlying regressors, for instance, I replace the unemployment rate gap by the real GDP gap, the survey measures of real growth uncertainty by an eight-quarter trailing standard deviation of the real GDP growth rate, and inflation uncertainty by a 24-month trailing standard deviation of core PCE price index inflation, respectively. ${ }^{11}$ The estimation results are very similar to the ones reported in Tables 1 to 5. Next I experiment with different sub-sample periods, in particular, I expand the crisis sample to include the period from August 2007 to August 2008. This period represents the first stage of the most recent financial crisis, during which financial markets, especially the inter-bank money market, experienced severe distress and the Federal Reserve responded by establishing several liquidity-injecting facilities as part of its effort to stabilize the markets (Wu 2011), but the federal funds rate had not yet been reduced to near zero and the FOMC had not started its unconventional monetary policy. Estimation results based on this sample period again are very close to the ones reported in Tables 1 and 4, and the estimated LSAP effects even become slightly larger. Finally, I experimented with alternative model specifications such as $\operatorname{AR}(1)$ specifications and differencing regressions. The estimated LSAP coefficients remain substantial and statistically significant.

\footnotetext{
${ }^{11}$ I also experimented with adding other potential determinants, for instance variables representing quantity of outstanding Treasury securities. The coefficient estimates are not statistically significant. Another possible determinant is foreign official purchases of U.S. Treasury securities; however, previous studies have not found a large and significant effect on bond yields by such purchases (Rudebusch, Swanson, and Wu 2006).
}

CInternational Monetary Fund. Not for Redistribution 
As explained in Section 3, different term structure model assumptions may yield different bond-yield decompositions, therefore the estimates of term premiums and the average of expected future short rates from these models will likely be different. To verify the robustness of the results obtained above, I re-estimate the model using two alternative model-based decompositions: D'Amico, Kim, and Wei (2010, DKW henceforth), and Adrian, Crump and Moench (2012, ACM henceforth). These models differ in their assumptions on the dynamics of the underlying term structure factors (3 latent factors in Kim-Wright (KW), 4 factors in DKW including an observable inflation factor, and 5 in $\mathrm{ACM}$ which are the first five principal components of term structure), estimation methods (full-scale non-linear maximum likelihood estimation in KW and DKW versus 3-step OLS in ACM), the data input (nominal zero-coupon Treasury bond yields in KW, both nominal and real zero-coupon Treasury yields in DKW, and nominal zero-coupon Treasury yields as well as constant maturity Treasury yields that bear coupons in ACM), etc. They represent a wide array of popular dynamic term structure models (DTSM) in the current literature, and my goal is to verify whether the conclusions drawn above are robust despite these heterogeneous model specifications and data inputs.

Estimation results based on the alternative bond yield decompositions are very close to those based on the Kim-Wright decomposition, as shown in Tables 6 to 8. In particular, term premiums are counter-cyclical, and react strongly to changes in consumer confidence and longrun inflation expectations, macroeconomic uncertainties and financial market volatilities (Table 6). The estimated LSAP effects are strikingly similar to the KW estimates, both quantitatively and in terms of statistical significance. For instance, during the "QE I" phase, the estimated LSAP effect on 10-year term premium is 35 basis points in $\mathrm{KW}$ sample, 41 basis points in ACM, and 33 basis points in DKW; the total LSAP effects from September 2008 to May 2013 are: 113 basis points in the KW sample, 132 basis points in ACM, and 106 basis points in the DKW sample, very close to each other.

Estimates of determination of the future short-term interest rates are also very similar across different bond-yield decompositions. As Table 8 shows, all three decompositions suggest that the average future short rates are counter-cyclical, reacting strongly to long-run and short-run inflation and inflation expectations, and less so to macroeconomic uncertainties and financial market volatilities than term premiums. The estimated LSAP effect in signaling future shortterm interest rates are also substantial and statistically significant from zero in all cases. Thus, 
we are confident that the conclusions drawn in Sections 4 to 6 are robust to different model specifications, sample periods, definitions of underlying variables, and data inputs.

\section{Concluding Remarks}

Recent studies have generally concluded that the unconventional monetary policies implemented in several countries, including the United States and the United Kingdom, during the most recent crisis have largely succeeded in providing additional policy stimulus after short-term interest rates become constrained by the zero lower bound (International Monetary Fund 2013a). Longterm interest rates have declined substantially in response to "forward guidance" and various asset purchasing policies in these countries. However, the transmission mechanism of such policies has not been fully clarified. In particular, the relative importance of "signaling effect" and "portfolio rebalance effect" remains the subject of academic and policy debates, and there is not yet a consensus on the quantitative assessment of the effectiveness of these two mechanisms over time.

This paper tackles these issues in a quantitative framework. I construct a real-time measure summarizing the market projections of the magnitude and persistence of the Federal Reserve's Large Scale Asset Purchase program, and separately examine how the LSAP and "forward guidance" have taken effect in lowering the expected future short-term interest rates and term premiums. Estimation results suggest that both the "signaling" channel and the "portfolio rebalance" channel are important in the unconventional monetary policies' transmission mechanism. Moreover, in addition to the conventional view that "forward guidance" adjusts the public's expectation of future short rates and that LSAPs lower the term premiums, there is strong evidence suggesting additional spillover effects: on the one hand, "forward guidance" leads to a gradual extension of market's projected length of the holding period of LSAP assets, thereby generating a far more persistent effect of the LSAP on term premiums; on the other hand, the continuing LSAPs also help to enhance the credibility of "forward guidance" and guide the market's expectations of future short-term interest rates, thereby generating a "signaling" effect. Estimation results also suggest that the effectiveness of the LSAP during the QE I, QE II, and Operation Twist phases is similar, but has declined substantially during the QE III phase. Finally, model simulations underscore the importance of policy transparency in minimizing unnecessary market turbulence and ensuring a timely and smooth exit of the unconventional 
monetary policy stimulus.

Examining how unconventional monetary policies have lowered the long-term government security yields is only the first step in understanding the whole transmission mechanism. The effectiveness of unconventional monetary policies has to be judged based on how such policies have lowered various private borrowing costs, and how the declines in private borrowing costs have eventually translated into expansion of real activity. While this study only focuses on the U.S. Treasury yields, the results have a direct bearing on these broader issues. Moreover, the constructed real-time measure of the LSAP is a powerful tool in further quantitative analyses of unconventional monetary policies, and the methodology developed in this paper can be extended to study similar policies in other countries. All these are interesting avenues for future research.

\section{Reference}

Adrian, Tobias, Richard K. Crump, and Emanuel Moench, 2012. "Pricing the Term Structure with Linear Regressions," Federal Reserve Bank of New York Staff Report, No. 340.

Ang, A. and M. Piazzesi, 2003, "No-Arbitrage Vector Autoregression of Term Structure Dynamics with Macroeconomic and Latent Variables," Journal of Monetary Economics 50, 745-787.

Bauer, Michael and Glenn Rudebusch, 2013. "The Signaling Channel for Federal Reserve Bond Purchases," Federal Reserve Bank of San Francisco Working Paper Series, 2011-21.

Bernanke, Ben, press conference release, September 18, 2013. Available at

http://www.federalreserve.gov/mediacenter/files/FOMCpresconf20130918.pdf.

Bernanke, Ben, Semiannual Monetary Policy Report to the Congress, July 17, 2013. Available at

http://www.federalreserve.gov/newsevents/testimony/bernanke20130717a.htm.

Bernanke, Ben, press conference release, June 19, 2013. Available at

http:// www.federalreserve.gov/mediacenter/files/FOMCpresconf20130619.pdf.

Chung, Hess, Jean-Philippe Laforte, David Reifschneider, and John C. Williams, 2012. "Have We Underestimated the Likelihood and Severity of Zero Lower Bound Events?" Journal of Money, Credit, and Banking, vol. 44, no. 1, pp. 47-82.

Duffie, D. and R. Kan, 1996. "A Yield-Factor Model of Interest Rates," Mathematical Finance 6, 379-406. 
D'Amico, Stefania, Don H. Kim, and Min Wei, 2010. "Tips from TIPS: the Informational Content of Treasury Inflation-Protected Security prices," FEDS Working Papers, Federal Reserve Board, 2010-19.

D'Amico, Stefania and Thomas B. King, 2013. "Flow and Stock Effects of Large-Scale Treasury Purchases: Evidence on the Importance of Local Supply," Journal of Financial Economics, vol. 108 , no. $2,425-448$.

Gagnon, Joseph, Matthew Raskin, Julie Remache, and Brian Sack, 2011. "The Financial Market Effects of the Federal Reserve's Large-Scale Asset Purchases," International Journal of Central Banking, vol. 7, no. 1, pp. 3-43.

Golay, Ellen Correia, Steven Friedman, and Michael McMorrow, 2013. "Understanding the New York Fed's Survey of Primary Dealers," Current Issues, The Federal Reserve Bank of New York, vol. 19, no. 6, pp. 1-8.

Hamilton, James D. and Jing Cynthia Wu, 2012. "The Effectiveness of Alternative Monetary Policy Tools in a Zero Lower Bound Environment," Journal of Money, Credit and Banking, vol. 44 , pp. 3-46.

International Monetary Fund, 2013a. "Unconventional Monetary Policies - Recent Experience and Prospects."

International Monetary Fund, 2013b. "The IMF's 2013 Article IV Consultation with the United States: Selected Issues."

Joyce, Michael, Ana Lasaosa, Ibrahim Stevens, and Matthew Tong, 2011. "The Financial Market Impact of Quantitative Easing in the United Kingdom," International Journal of Central Banking, vol. 7, no. 3, pp. 113-161.

Kim, Don H., and Jonathan H. Wright, 2005. "An Arbitrage-Free Three-Factor Term Structure Model and the Recent Behavior of Long-Term Yields and Distant-Horizon Forward Rates," FEDS Working Papers, Federal Reserve Board, 2005-33.

Krishnamurthy, Arvind and Annette Vissing-Jorgensen, 2011. "The Effects of Quantitative Easing on Interest Rates: Channels and Implications for Policy," Brookings Papers on Economic Activity, Fall 2011, pp. 215-265.

Neely, Christopher J., 2012. "The Large-Scale Asset Purchases Had Large International Effects," Federal Reserve Bank of St. Louis Working Paper Series, 2010-018D.

Tobin, James, 1961. "Money, Capital and Other Stores of Value," American Economic 
Review, vol. 51, no. 2, pp. 26-37.

Rudebusch, Glenn, Eric Swanson, and Tao Wu, 2006. "The Bond Yield 'Conundrum' from a Macro-Finance Perspective." Monetary and Economic Studies, vol. 24, no. S-1, 83-109.

Rudebusch, Glenn, and Tao Wu, 2008. "A Macro-Finance Model of the Term Structure, Monetary Policy, and the Economy," Economic Journal, vol. 118, pp. 1-21.

Woodford, Michael, 2012. "Methods of Policy Accommodation at the Interest-Rate Lower Bound," manuscript, Columbia University.

Wu, Tao, 2006. "Macro Factors and the Affine Term Structure of Interest Rates," Journal of Money, Credit, and Banking, vol. 38, no. 7, pp. 1847-1875.

Wu, Tao, 2011. "The U.S. Money Market and the Term Auction Facility in the Financial Crisis of 2007-2009," Review of Economics and Statistics, vol. 93, no. 2, pp. 617-631. 
Table 1: Determination of Ten-Year Term Premium

\begin{tabular}{|c|c|c|c|}
\hline & $\begin{array}{c}\text { Whole Sample } \\
\text { (Jan. } 92 \text { - Sep. 13) }\end{array}$ & $\begin{array}{l}\text { Pre-Crisis Sample } \\
\text { (Jan. } 92 \text { - Aug. 08) }\end{array}$ & $\begin{array}{c}\text { Crisis Sample } \\
\text { (Sep. 08 - Sep. 13) }\end{array}$ \\
\hline \multicolumn{4}{|l|}{ Macroeconomic fundamentals } \\
\hline Unemployment rate gap & $\begin{array}{c}0.0780 \\
(1.4378)\end{array}$ & $\begin{array}{c}0.1643 \\
(1.8970)\end{array}$ & $\begin{array}{l}0.2288^{* *} \\
(2.7103)\end{array}$ \\
\hline Consumer confidence expectation & $\begin{array}{l}0.0174^{* *} \\
(8.3913)\end{array}$ & $\begin{array}{l}0.0197^{* *} \\
(7.6072)\end{array}$ & $\begin{array}{c}0.0052 \\
(1.5096)\end{array}$ \\
\hline 10-year-ahead CPI inflation forecast & $\begin{array}{c}1.2560^{* *} \\
(12.5867)\end{array}$ & $\begin{array}{l}1.1517^{* *} \\
(9.2658)\end{array}$ & $\begin{array}{c}-0.3891 \\
(-0.8326)\end{array}$ \\
\hline One-year ahead inflation expectation & $\begin{array}{c}0.0493 \\
(1.0855)\end{array}$ & $\begin{array}{c}0.0691 \\
(1.3245)\end{array}$ & $\begin{array}{l}0.3460^{* *} \\
(5.9414)\end{array}$ \\
\hline 12-month core PCEPI inflation & $\begin{array}{l}-0.0463 \\
(-0.4964)\end{array}$ & $\begin{array}{c}0.0858 \\
(0.7446)\end{array}$ & $\begin{array}{l}-0.2577^{*} \\
(-2.3032)\end{array}$ \\
\hline \multicolumn{4}{|l|}{ Macroeconomic uncertainties } \\
\hline Real growth uncertainty & $\begin{array}{l}0.3724^{* *} \\
(3.1159)\end{array}$ & $\begin{array}{c}0.2343 \\
(1.7958)\end{array}$ & $\begin{array}{l}0.9488^{* *} \\
(4.2465)\end{array}$ \\
\hline Unemployment rate uncertainty & $\begin{array}{l}0.5246^{* *} \\
(2.6574)\end{array}$ & $\begin{array}{l}0.6892^{* *} \\
(3.3840)\end{array}$ & $\begin{array}{c}0.0246 \\
(0.0609)\end{array}$ \\
\hline Inflation uncertainty & $\begin{array}{l}-0.2973^{*} \\
(-2.4294)\end{array}$ & $\begin{array}{l}-0.1453 \\
(-0.9518)\end{array}$ & $\begin{array}{l}-0.7576^{* *} \\
(-3.5534)\end{array}$ \\
\hline \multicolumn{4}{|c|}{ Financial market volatility and policy-rate uncertainty } \\
\hline MOVE & $\begin{array}{l}0.6392^{* *} \\
(4.5301)\end{array}$ & $\begin{array}{l}0.6370^{* *} \\
(3.2621)\end{array}$ & $\begin{array}{l}0.8893^{* *} \\
(4.5073)\end{array}$ \\
\hline VIX & $\begin{array}{l}-0.7118 \\
(-1.4693)\end{array}$ & $\begin{array}{c}0.7717 \\
(1.0291)\end{array}$ & $\begin{array}{l}-1.2404 \\
(-1.4927)\end{array}$ \\
\hline Six-month Eurodollar implied vol & $\begin{array}{c}0.2708 \\
(1.0247)\end{array}$ & $\begin{array}{c}0.0919 \\
(0.1658)\end{array}$ & $\begin{array}{c}0.1705 \\
(0.5723)\end{array}$ \\
\hline PDV of SOMA balance ( $L S A P)$ & $\begin{array}{l}-0.0112^{* *} \\
(-6.3887)\end{array}$ & - & $\begin{array}{l}-0.0062^{*} \\
(-2.4089)\end{array}$ \\
\hline $\mathrm{R}^{2}$ & 0.8792 & 0.8461 & 0.9030 \\
\hline Adj. $R^{2}$ & 0.8386 & 0.7993 & 0.7224 \\
\hline
\end{tabular}

Note: $t$-statistics are displayed in parentheses. ${ }^{*}$ and ${ }^{* *}$ denotes statistical significance at the $5 \%$ and $1 \%$ level, respectively. 
Table 2: Decomposition of Changes in Ten-Year Term Premium:

September 2008 to May 2013

Changes in 10-year Treasury Bond Yields (basis points, same below) $\quad-217.1$

of which:

Changes in 10-year Term Premium

$-114.0$

of which:

Changes in Macroeconomic Fundamentals

Changes in Macroeconomic Uncertainties

$-18.7$

Changes in Financial Market Volatilities and

Near-future Policy-rate Uncertainty

Changes in the PDV of Excess SOMA Balance

$-112.8$

of which:

"QE I" Phase

"QE II" Phase

$-8.6$

"Operation Twist" Phase

$-19.1$

"QE III" Phase

Periods w/o Active Purchases (e.g., April-October 2010, and July-August 2011)

Residual

10.9

Note: Changes in 10-year Treasury bond yields and term premiums are from Federal Reserve Board and Kim-Wright (2005) estimation, respectively. Others are based on author's calculation. 
Table 3: Effects of LSAP and "Forward Guidance" on Ten-Year Term Premium

\begin{tabular}{|c|c|c|}
\hline \multirow{2}{*}{ Macroeconomic fundamentals } & \multicolumn{2}{|c|}{$\begin{array}{c}\text { Whole Sample } \\
\text { (Jan. 92 - Sep. 13) }\end{array}$} \\
\hline & & \\
\hline Unemployment rate gap & $\begin{array}{c}0.0927 \\
(1.4036)\end{array}$ & $\begin{array}{c}0.0693 \\
(1.0647)\end{array}$ \\
\hline Consumer confidence exp & $\begin{array}{c}0.0194^{* *} \\
(9.5272)\end{array}$ & $\begin{array}{l}0.0189^{* *} \\
(9.0772)\end{array}$ \\
\hline 10-year-ahead CPI inflation forecast & $\begin{array}{l}1.2373^{* *} \\
(12.3206)\end{array}$ & $\begin{array}{c}1.2331^{* *} \\
(11.9703)\end{array}$ \\
\hline One-year ahead inflation expectation & $\begin{array}{c}0.0787 \\
(1.5257)\end{array}$ & $\begin{array}{c}0.0602 \\
(1.1686)\end{array}$ \\
\hline 12-month core PCEPI inflation & $\begin{array}{c}0.0393 \\
(0.4063)\end{array}$ & $\begin{array}{c}0.0583 \\
(0.6026)\end{array}$ \\
\hline \multicolumn{3}{|l|}{ Macroeconomic uncertainties } \\
\hline Real growth uncertainty & $\begin{array}{l}0.2539^{*} \\
(2.1067)\end{array}$ & $\begin{array}{l}0.2666^{*} \\
(2.1756)\end{array}$ \\
\hline Unemployment rate uncertainty & $\begin{array}{l}0.6306^{* *} \\
(3.3632)\end{array}$ & $\begin{array}{l}0.5813^{* *} \\
(3.0243)\end{array}$ \\
\hline Inflation uncertainty & $\begin{array}{c}-0.1821 \\
(-1.6647)\end{array}$ & $\begin{array}{l}-0.1940 \\
(-1.7054)\end{array}$ \\
\hline \multicolumn{3}{|c|}{ Financial market volatility and policy-rate uncertainty } \\
\hline MOVE & $\begin{array}{l}0.5055^{* *} \\
(3.5380)\end{array}$ & $\begin{array}{l}0.5884^{* *} \\
(4.0834)\end{array}$ \\
\hline VIX & $\begin{array}{l}-0.0065 \\
(-0.0135)\end{array}$ & $\begin{array}{l}-0.1663 \\
(-0.3413)\end{array}$ \\
\hline Six-month Eurodollar implied vol & $\begin{array}{c}0.4625 \\
(1.9254)\end{array}$ & $\begin{array}{c}0.3805 \\
(1.4801)\end{array}$ \\
\hline $\mathbf{L S A P} \mathbf{P}^{N}$ & $\begin{array}{l}-0.0191^{*} \\
(-2.4566)\end{array}$ & $\begin{array}{l}-0.0086 \\
(-1.4598)\end{array}$ \\
\hline$L S A P^{N} * d u m m y(Q E I)$ & $\begin{array}{c}0.0065 \\
(1.7833)\end{array}$ & - \\
\hline$L S A P^{N} * d u m m y(Q E I I)$ & $\begin{array}{l}0.0076^{*} \\
(2.1159)\end{array}$ & - \\
\hline$L S A P^{N} * d u m m y(O T)$ & $\begin{array}{c}-0.0003 \\
(-0.0382)\end{array}$ & - \\
\hline$L S A P^{N} * d u m m y(Q E I I I)$ & $\begin{array}{c}0.0157^{* *} \\
(2.6962)\end{array}$ & - \\
\hline
\end{tabular}

(Table 3 continued on next page) 
(Table 3 continued)

Whole Sample
(Jan. 92 - Sep. 13)

\begin{tabular}{|c|c|c|}
\hline$\left(\mathbf{L S A P}-\mathbf{L S A P}^{N}\right)$ & $\begin{array}{l}-0.0182^{*} \\
(-2.2956)\end{array}$ & $\begin{array}{l}-0.0212^{* *} \\
(-3.1365)\end{array}$ \\
\hline$\left(L S A P-L S A P^{N}\right) * d u m m y(Q E I I)^{1}$ & - & $\begin{array}{c}0.0091 \\
(1.0662)\end{array}$ \\
\hline$\left(L S A P-L S A P^{N}\right) * d u m m y(O T)$ & - & $\begin{array}{c}-0.0035 \\
(-0.5546)\end{array}$ \\
\hline$\left(L S A P-L S A P^{N}\right) * d u m m y(Q E I I I)$ & - & $\begin{array}{c}0.0127 \\
(1.5001)\end{array}$ \\
\hline $\mathrm{R}^{2}$ & 0.8976 & 0.8943 \\
\hline Adj. $R^{2}$ & 0.8389 & 0.8393 \\
\hline$\chi^{2}$ (all four dummies are zero) & $25.69^{* *}$ & $17.17^{* *}$ \\
\hline$\chi^{2}$ (dummies on QE I, II, OT are zero) & 4.43 & 2.05 \\
\hline
\end{tabular}

Note: $t$-statistics are displayed in parentheses. ${ }^{*}$ and ${ }^{* *}$ denotes statistical significance at the $5 \%$ and $1 \%$ level, respectively.

\footnotetext{
${ }^{1}$ The $L S A P$ and $L S A P^{N}$ measures are identical during the QE I period, as the market had not substantially changed their expectations on the federal funds rate "lift off" or the length of holding period of these QE I assets. Thus here it is infeasible to construct a dummy for "forward guidance" in QE I phase.
} 
Table 4: Determination of the Average of Expected Future Short Rates

\begin{tabular}{|c|c|c|c|}
\hline & $\begin{array}{c}\text { Whole Sample } \\
\text { (Jan. } 92 \text { - Sep. 13) }\end{array}$ & $\begin{array}{l}\text { Pre-Crisis Sample } \\
\text { (Jan. } 92 \text { - Aug. 08) }\end{array}$ & $\begin{array}{c}\text { Crisis Sample } \\
\text { (Sep. 08 - Sep. 13) }\end{array}$ \\
\hline \multicolumn{4}{|l|}{ Macroeconomic fundamentals } \\
\hline Unemployment rate gap & $\begin{array}{c}-0.2794^{* *} \\
(-4.7928)\end{array}$ & $\begin{array}{l}-0.5523^{* *} \\
(-9.9154)\end{array}$ & $\begin{array}{c}0.0496 \\
(1.1697)\end{array}$ \\
\hline Consumer confidence exp & $\begin{array}{l}0.0094^{* *} \\
(4.1518)\end{array}$ & $\begin{array}{l}0.0080^{* *} \\
(5.3874)\end{array}$ & $\begin{array}{c}0.0008 \\
(0.5495)\end{array}$ \\
\hline 10-year-ahead CPI inflation forecast & $\begin{array}{l}1.2824^{* *} \\
(10.7488)\end{array}$ & $\begin{array}{l}1.2385^{* *} \\
(13.1300)\end{array}$ & $\begin{array}{c}-0.3357 \\
(-1.6524)\end{array}$ \\
\hline One-year ahead inflation expectation & $\begin{array}{l}0.1343^{* *} \\
(3.0031)\end{array}$ & $\begin{array}{c}-0.0095 \\
(-0.2938)\end{array}$ & $\begin{array}{l}0.1700^{* *} \\
(4.0897)\end{array}$ \\
\hline 12-month core PCEPI inflation & $\begin{array}{l}-0.2666^{* *} \\
(-3.2383)\end{array}$ & $\begin{array}{l}0.1457^{* *} \\
(2.5117)\end{array}$ & $\begin{array}{l}-0.0746 \\
(-1.3025)\end{array}$ \\
\hline \multicolumn{4}{|l|}{ Macroeconomic uncertainties } \\
\hline Real growth uncertainty & $\begin{array}{c}-0.0183 \\
(-0.1136)\end{array}$ & $\begin{array}{c}-0.1485 \\
(-1.4617)\end{array}$ & $\begin{array}{l}0.3750^{* *} \\
(4.1971)\end{array}$ \\
\hline Unemployment rate uncertainty & $\begin{array}{l}0.9396^{* *} \\
(3.7581)\end{array}$ & $\begin{array}{l}0.4113^{* *} \\
(2.9997)\end{array}$ & $\begin{array}{l}-0.0578 \\
(-0.3370)\end{array}$ \\
\hline Inflation uncertainty & $\begin{array}{l}-0.0748 \\
(-0.4606)\end{array}$ & $\begin{array}{c}0.0130 \\
(0.0960)\end{array}$ & $\begin{array}{c}-0.2977^{* *} \\
(-3.4664)\end{array}$ \\
\hline \multicolumn{4}{|c|}{ Financial market volatility and policy-rate uncertainty } \\
\hline MOVE & $\begin{array}{l}-0.4142^{*} \\
(-2.3962)\end{array}$ & $\begin{array}{l}0.3514^{*} \\
(2.2451)\end{array}$ & $\begin{array}{l}0.4030^{* *} \\
(4.3654)\end{array}$ \\
\hline VIX & $\begin{array}{c}0.7091 \\
(1.4388)\end{array}$ & $\begin{array}{l}0.7159^{*} \\
(1.8672)\end{array}$ & $\begin{array}{l}-0.5854 \\
(-1.5154)\end{array}$ \\
\hline Six-month Eurodollar implied vol & $\begin{array}{l}-0.0462 \\
(-0.1230)\end{array}$ & $\begin{array}{c}-1.4130^{* *} \\
(-3.3403)\end{array}$ & $\begin{array}{l}-0.0219 \\
(-0.1651)\end{array}$ \\
\hline PDV of SOMA balance $(L S A P)$ & $\begin{array}{l}-0.0083^{* *} \\
(-5.1300)\end{array}$ & - & $\begin{array}{l}-0.0053^{* *} \\
(-4.9127)\end{array}$ \\
\hline $\mathrm{R}^{2}$ & 0.8872 & 0.9106 & 0.9079 \\
\hline Adj. $R^{2}$ & 0.8463 & 0.8602 & 0.7263 \\
\hline
\end{tabular}

Note: $t$-statistics are displayed in parentheses. ${ }^{*}$ and ${ }^{* *}$ denotes statistical significance at the $5 \%$ and $1 \%$ level, respectively. 
Table 5: Determination of the Average of Expected Future Short Rates: Alternative $L S A P^{N}$ Measure

\begin{tabular}{lcc}
\hline & $\begin{array}{c}\text { Whole Sample } \\
\text { (Jan. 92 - Sep. 13) }\end{array}$ & $\begin{array}{c}\text { Crisis Samp } \\
\text { (Sep. 08 - Sep. }\end{array}$ \\
\hline \hline Macroeconomic fundamentals & & $0.1112^{*}$ \\
Unemployment rate gap & $-0.2623^{* *}$ & $(2.2863)$ \\
Consumer confidence exp & $(-4.2327)$ & 0.0013 \\
& $0.0108^{* *}$ & $(0.7663)$ \\
10-year-ahead CPI inflation forecast & $(4.5963)$ & -0.3975 \\
& $1.2484^{* *}$ & $(-1.7457)$ \\
One-year ahead inflation expectation & $(9.9056)$ & $0.2078^{* *}$ \\
& $0.1215^{* *}$ & $(5.2708)$ \\
12-month core PCEPI inflation & $(2.5664)$ & -0.0598 \\
& $-0.2299^{*}$ & $(-0.7985)$ \\
Macroeconomic uncertainties & $(-2.4173)$ & \\
Real growth uncertainty & & $0.5051^{* *}$ \\
Unemployment rate uncertainty & 0.0994 & $(5.4559)$ \\
& $(0.5911)$ & 0.0885 \\
Inflation uncertainty & $1.0297^{* *}$ & $(0.4855)$ \\
& $(4.0784)$ & $-0.4173^{* *}$ \\
& -0.0237 & $(-3.8124)$
\end{tabular}

Financial market volatility and policy-rate uncertainty

$\begin{array}{lcc}\text { MOVE } & -0.2243 & 0.5598^{* *} \\ & (-1.3162) & (5.2878) \\ \text { VIX } & 0.5789 & -0.4750 \\ & (1.0951) & (-0.9685) \\ \text { Six-month Eurodollar implied vol } & -0.3678 & -0.0741 \\ & (-0.9680) & (-0.4466) \\ L S A P^{N} & & -0.0037 \\ & -0.0076^{*} & (-1.6128) \\ \mathrm{R}^{2} & (-2.2898) & 0.8758 \\ \mathrm{Adj} . \mathrm{R}^{2} & & 0.7006\end{array}$

Note: $t$-statistics are displayed in parentheses. ${ }^{*}$ and ${ }^{* *}$ denotes statistical significance at the $5 \%$ and $1 \%$ level, respectively. 
Table 6: Determination of Ten-Year Term Premium: Robustness Check

\begin{tabular}{|c|c|c|c|}
\hline & KW & $\mathrm{ACM}$ & DKW \\
\hline \multicolumn{4}{|l|}{ Macroeconomic fundamentals } \\
\hline Unemployment rate gap & $\begin{array}{c}0.0780 \\
(1.4378)\end{array}$ & $\begin{array}{c}0.2662^{* *} \\
(3.3238)\end{array}$ & $\begin{array}{c}0.0888 \\
(1.5890)\end{array}$ \\
\hline Consumer confidence expectation & $\begin{array}{l}0.0174^{* *} \\
(8.3913)\end{array}$ & $\begin{array}{c}0.0111^{* *} \\
(3.7757)\end{array}$ & $\begin{array}{l}0.0141^{* *} \\
(7.1740)\end{array}$ \\
\hline 10-year-ahead CPI inflation forecast & $\begin{array}{c}1.2560^{* *} \\
(12.5867)\end{array}$ & $\begin{array}{l}1.0035^{* *} \\
(6.3871)\end{array}$ & $\begin{array}{c}1.1146^{* *} \\
(11.2575)\end{array}$ \\
\hline One-year ahead inflation expectation & $\begin{array}{c}0.0493 \\
(1.0855)\end{array}$ & $\begin{array}{c}-0.0295 \\
(-0.4702)\end{array}$ & $\begin{array}{c}0.0167 \\
(0.3660)\end{array}$ \\
\hline 12-month core PCEPI inflation & $\begin{array}{c}-0.0463 \\
(-0.4964)\end{array}$ & $\begin{array}{c}0.0843 \\
(0.7056)\end{array}$ & $\begin{array}{c}-0.0343 \\
(-0.3714)\end{array}$ \\
\hline \multicolumn{4}{|l|}{ Macroeconomic uncertainties } \\
\hline Real growth uncertainty & $\begin{array}{l}0.3724^{* *} \\
(3.1159)\end{array}$ & $\begin{array}{c}0.3920^{*} \\
(2.0221)\end{array}$ & $\begin{array}{l}0.3506^{* *} \\
(2.8213)\end{array}$ \\
\hline Unemployment rate uncertainty & $\begin{array}{l}0.5246^{* *} \\
(2.6574)\end{array}$ & $\begin{array}{l}-0.1107 \\
(-0.3776)\end{array}$ & $\begin{array}{l}0.5006^{* *} \\
(2.5858)\end{array}$ \\
\hline Inflation uncertainty & $\begin{array}{l}-0.2973^{*} \\
(-2.4294)\end{array}$ & $\begin{array}{c}-0.2743 \\
(-1.3884)\end{array}$ & $\begin{array}{l}-0.2871^{*} \\
(-2.2640)\end{array}$ \\
\hline \multicolumn{4}{|c|}{ Financial market volatility and policy-rate uncertainty } \\
\hline MOVE & $\begin{array}{l}0.6392^{* *} \\
(4.5301)\end{array}$ & $\begin{array}{l}1.1462^{* *} \\
(5.1045)\end{array}$ & $\begin{array}{c}0.7164^{* *} \\
(4.9589)\end{array}$ \\
\hline VIX & $\begin{array}{c}-0.7118 \\
(-1.4693)\end{array}$ & $\begin{array}{c}-1.0104 \\
(-1.3513)\end{array}$ & $\begin{array}{c}-0.9741 \\
(-1.9058)\end{array}$ \\
\hline Six-month Eurodollar implied vol & $\begin{array}{c}0.2708 \\
(1.0247)\end{array}$ & $\begin{array}{l}1.1614^{* *} \\
(2.7838)\end{array}$ & $\begin{array}{c}0.3286 \\
(1.2138)\end{array}$ \\
\hline PDV of SOMA balance $(L S A P)$ & $\begin{array}{c}-0.0112^{* *} \\
(-6.3887)\end{array}$ & $\begin{array}{c}-0.0130^{* *} \\
(-4.7329)\end{array}$ & $\begin{array}{c}-0.0105^{* *} \\
(-5.8647)\end{array}$ \\
\hline $\mathrm{R}^{2}$ & 0.8792 & 0.7746 & 0.8525 \\
\hline Adj. $R^{2}$ & 0.8386 & 0.7388 & 0.8132 \\
\hline
\end{tabular}

Note: $t$-statistics are displayed in parentheses. ${ }^{*}$ and ${ }^{* *}$ denotes statistical significance at the $5 \%$ and $1 \%$ level, respectively. 
Table 7: Decomposition of Changes in Ten-Year Term Premium:

September 2008 to May 2013, Alternative Bond Yield Decompositions

\begin{tabular}{|c|c|c|c|}
\hline & KW & $\mathrm{ACM}$ & DKW \\
\hline $\begin{array}{l}\text { Changes in 10-year Treasury Bond Yields (basis points, same below) } \\
\text { of which: }\end{array}$ & -217.1 & -217.1 & -217.1 \\
\hline $\begin{array}{l}\text { Changes in 10-year Term Premium } \\
\text { of which: }\end{array}$ & -114.0 & -93.9 & -79.9 \\
\hline Changes in Macroeconomic Fundamentals & 26.1 & 34.0 & 25.5 \\
\hline Changes in Macroeconomic Uncertainties & -18.7 & -5.7 & -17.5 \\
\hline $\begin{array}{l}\text { Changes in Financial Market Volatilities and } \\
\text { Near-future Policy-rate Uncertainty }\end{array}$ & -19.5 & -18.6 & -19.9 \\
\hline $\begin{array}{l}\text { Changes in the PDV of Excess SOMA Balance } \\
\text { of which: }\end{array}$ & -112.8 & -131.5 & -106.0 \\
\hline "QE I" Phase & -34.9 & -40.6 & -32.7 \\
\hline "QE II" Phase & -8.6 & -10.0 & -8.0 \\
\hline "Operation Twist" Phase & -19.1 & -22.2 & -17.9 \\
\hline "QE III" Phase & -26.1 & -30.4 & -24.5 \\
\hline $\begin{array}{l}\text { Periods w/o Active Purchases (e.g., April-October } 2010 \text {, } \\
\text { and July-August 2011) }\end{array}$ & -24.1 & -28.3 & -22.9 \\
\hline Residual & 10.9 & 27.9 & 38.0 \\
\hline
\end{tabular}

Note: Changes in 10-year Treasury bond yields and term premiums are from Federal Reserve Board and Kim-Wright (2005) estimation, respectively. Others are based on author's calculation. 
Table 8: Determination of the Average of Expected Future Short Rates: Robustness Check

\begin{tabular}{lccc}
\hline & KW & ACM & DKW \\
\hline \hline Macroeconomic fundamentals & & & \\
Unemployment rate gap & $-0.2794^{* *}$ & $-0.4688^{* *}$ & $-0.0667^{* *}$ \\
& $(-4.7928)$ & $(-4.5630)$ & $(-3.9739)$ \\
Consumer confidence exp & $0.0094^{* *}$ & $0.0144^{* *}$ & $0.0033^{* *}$ \\
& $(4.1518)$ & $(3.8595)$ & $(5.3251)$ \\
10-year-ahead CPI inflation forecast & $1.2824^{* *}$ & $1.5707^{* *}$ & $0.4016^{* *}$ \\
& $(10.7488)$ & $(7.3742)$ & $(12.1433)$ \\
One-year ahead inflation expectation & $0.1343^{* *}$ & $0.2244^{* *}$ & $0.0398^{* *}$ \\
& $(3.0031)$ & $(2.9320)$ & $(3.3608)$ \\
12-month core PCEPI inflation & $-0.2666^{* *}$ & $-0.4477^{* *}$ & $-0.0817^{* *}$ \\
& $(-3.2383)$ & $(-3.2179)$ & $(-3.3287)$ \\
Macroeconomic uncertainties & & & \\
Real growth uncertainty & & & \\
Unemployment rate uncertainty & -0.0183 & -0.0789 & 0.0150 \\
& $(-0.1136)$ & $(-0.2875)$ & $(0.3352)$ \\
Inflation uncertainty & $0.9396^{* *}$ & $1.4843^{* *}$ & $0.2781^{* *}$ \\
& $(3.7581)$ & $(3.5749)$ & $(4.0856)$ \\
& -0.0748 & -0.0505 & -0.0332 \\
& $(-0.4606)$ & $(-0.1805)$ & $(-0.7151)$
\end{tabular}

Financial market volatility and policy-rate uncertainty

$\begin{array}{lccc}\text { MOVE } & -0.4142^{*} & -0.9077^{* *} & -0.0698 \\ & (-2.3962) & (-3.0021) & (-1.4931) \\ \text { VIX } & 0.7091 & 1.1221 & 0.0969 \\ & (1.4388) & (1.3110) & (0.7036) \\ \text { Six-month Eurodollar implied vol } & -0.0462 & -0.9363 & -0.0438 \\ & (-0.1230) & (-1.3952) & (-0.4031) \\ & & & \\ \text { PDV of SOMA balance (LSAP) } & -0.0083^{* *} & -0.0060^{*} & -0.0027^{* *} \\ & (-5.1300) & (-2.1154) & (-5.7045) \\ \mathrm{R}^{2} & & & \\ \text { Adj. R } & 0.8872 & 0.8684 & 0.9012 \\ & 0.8463 & 0.8283 & 0.8596\end{array}$

Note: $t$-statistics are displayed in parentheses. ${ }^{*}$ and ${ }^{* *}$ denotes statistical significance at the $5 \%$ and $1 \%$ level, respectively. 
Figure 1: Evolution of Market-Projected Path of Excess SOMA Holding

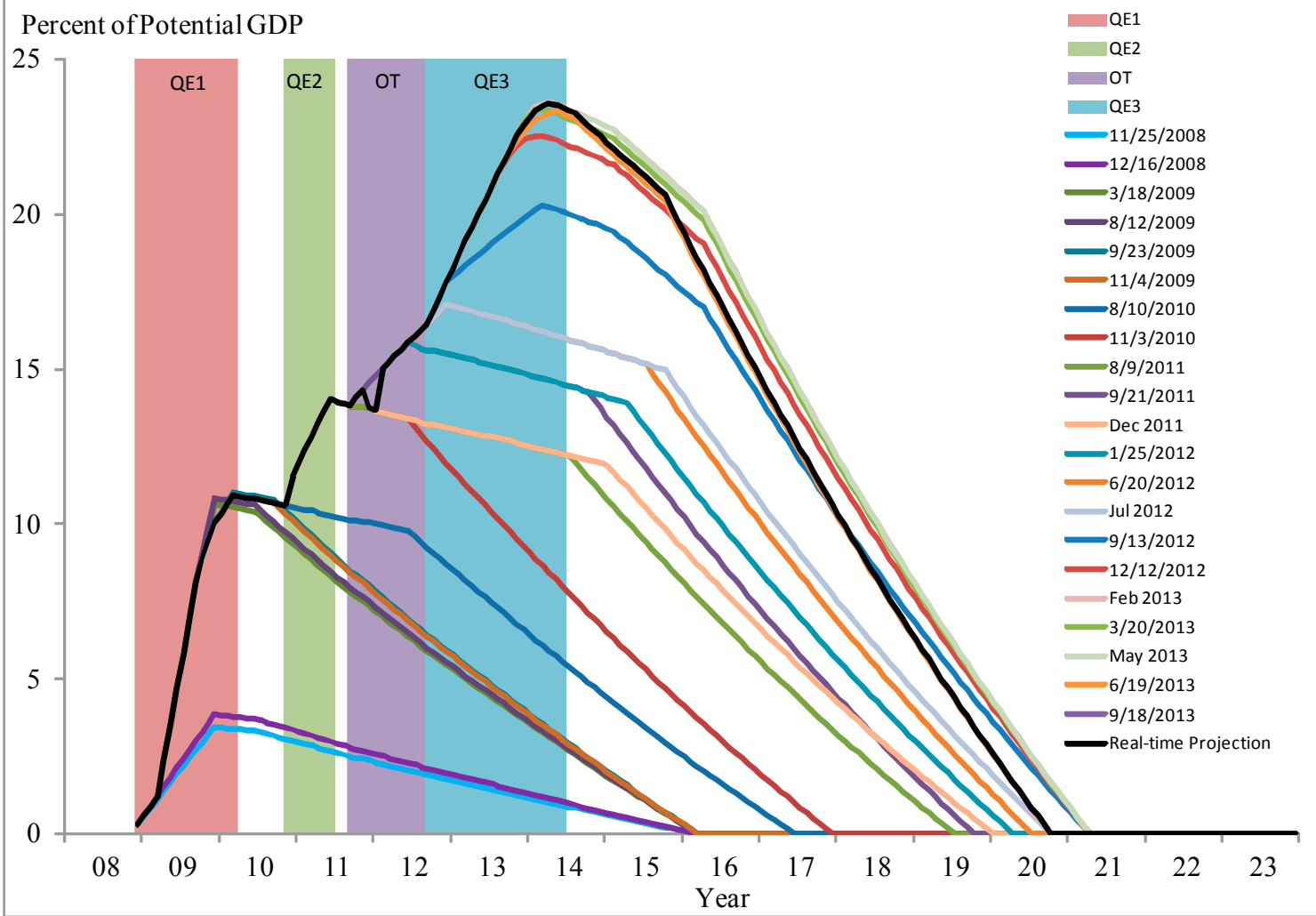

Figure 2: Present Discounted Value of Market's Projected SOMA Balance Percent of Potential GDP

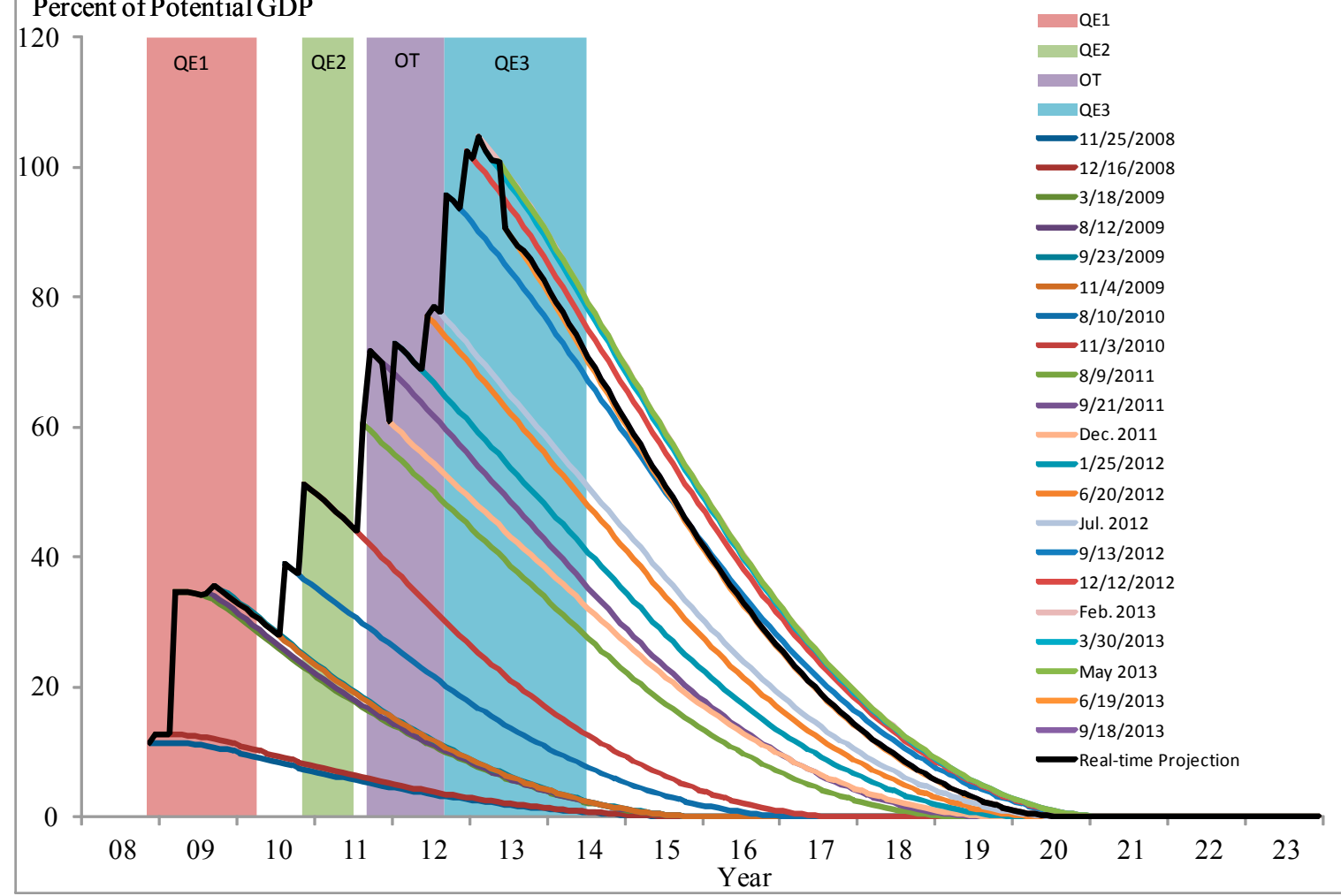




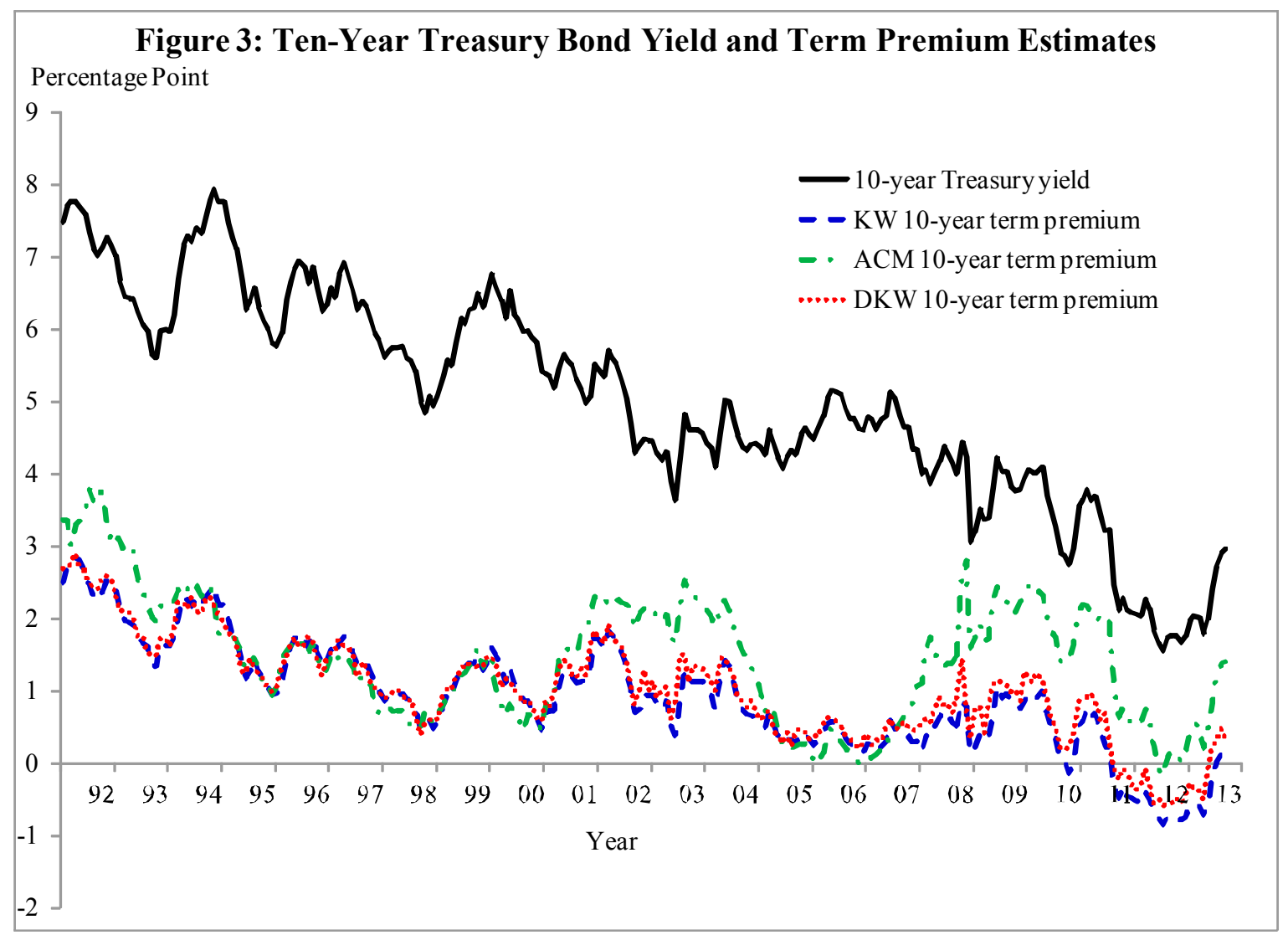

Figure 4: Real-Time and Counter-Factual LSAP Measures

Percent of Potential GDP

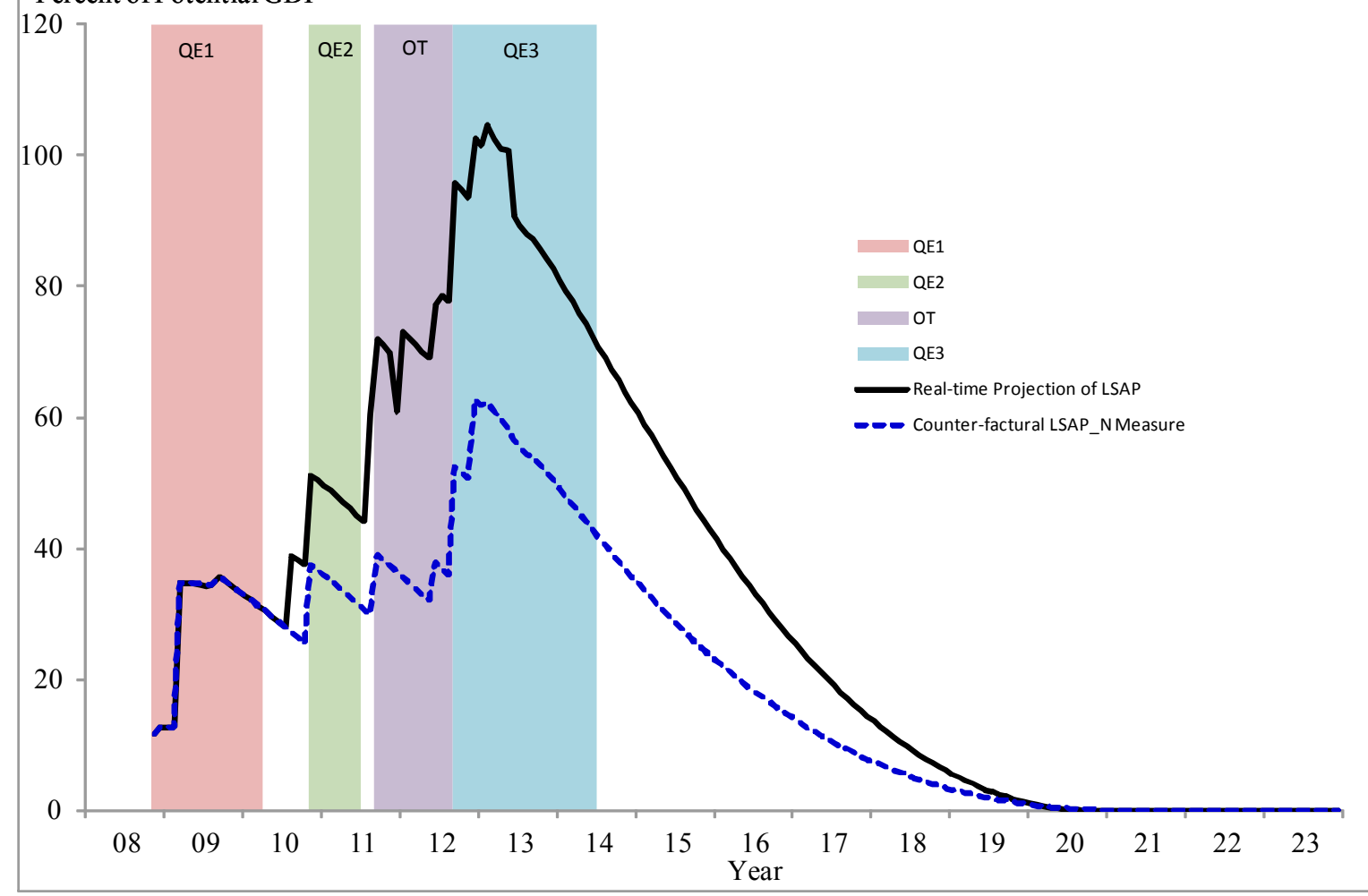




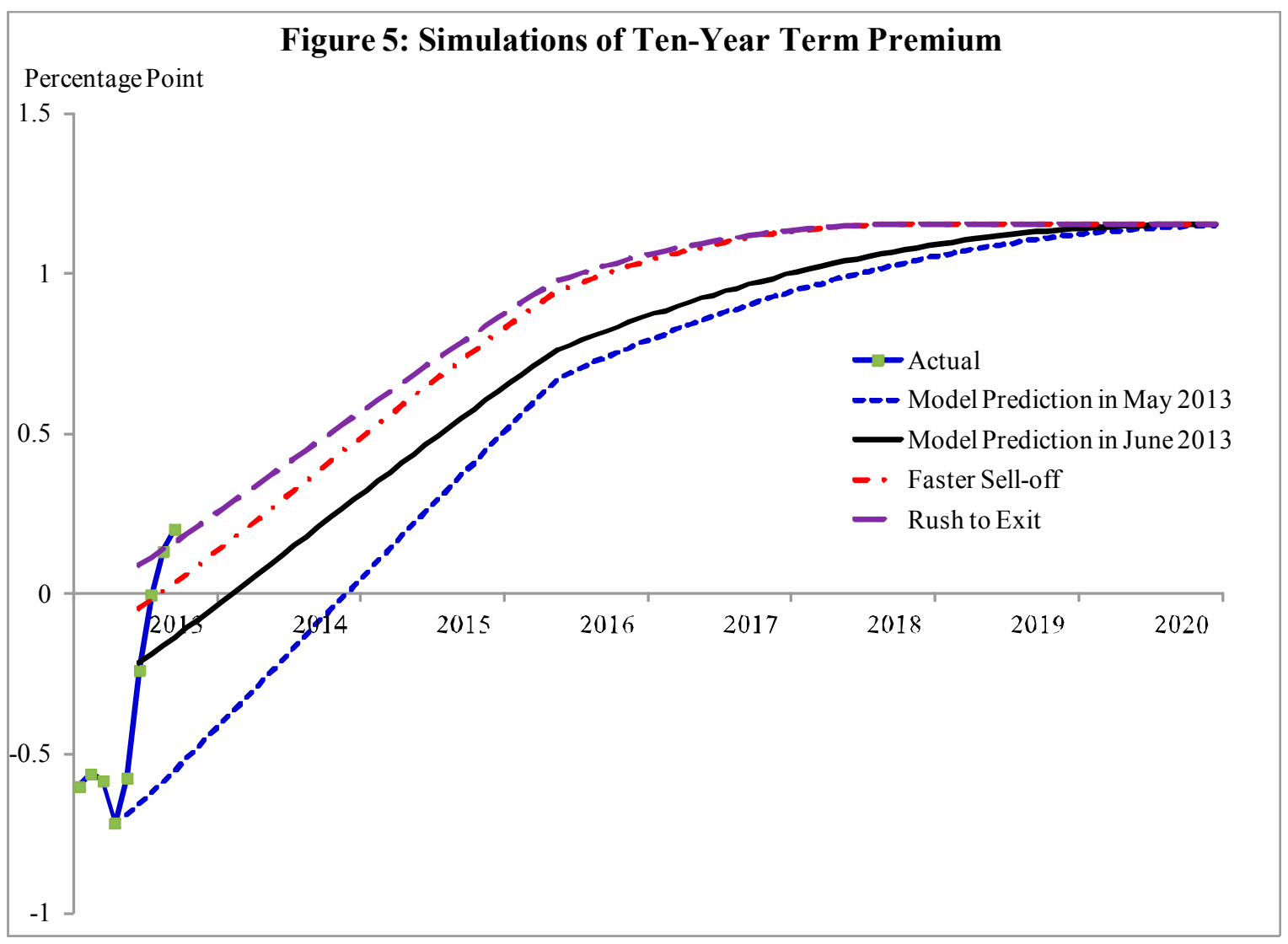




\section{Technical Appendix: Construction of the Real-Time LSAP Measures}

The LSAP measures are constructed by incorporating official FOMC policy announcements and real-time market information from various sources, in particular the Survey of Primary Dealers compiled by the Federal Reserve Bank of New York. The survey contains valuable information about market expectations of future monetary policy, for instance, on how soon the FOMC may "taper" the QE III purchases, when the first federal funds rate "lift-off" is expected to occur, and the likely size of the SOMA balance in the following five years, etc.

The first step in constructing the LSAP measures is to impute the market participants' projections of future excess SOMA balance at each point of time since November 2008. Therefore, in addition to the explicit LSAP announcements by the FOMC as listed in Table A1, I also need to trace how the market's expectations of the future LSAP program evolve over time, for instance, on the monthly pace of the asset purchases that have already been announced, or when and how soon the purchased LSAP assets will be sold off, and when the size of the Fed's balance sheet is expected to return to normal, which are closely related to the Fed's "forward guidance" policy. The Survey of Primary Dealers contains key information based on which the

market projections of future SOMA balance paths can be imputed, with a minimal number of assumptions to be made.

In particular, in constructing the real-time LSAP measures, the following observations and assumptions are utilized:

1) Market participants anticipate that the FOMC will implement the announced asset purchases in a steady pace within the announced time frame. For instance, when the FOMC announced on November 3, 2010 that it "intends to purchase a further $\$ 600$ billion of longerterm Treasury securities by the end of the second quarter of 2011," I assume that the market expects a purchasing pace of about $\$ 75$ billion each month from November 2010 to June 2011.

2) I assume that the market participants anticipate a steady pace for the FOMC to sell off the LSAP assets during the "exit." Moreover, the projected SOMA balance paths are imputed based on the following observations and assumptions:

i. Throughout the QE I period (November 2008 to March 2010), market participants had generally anticipated that the purchased assets would be sold off and the Fed's balance sheet 
would return to normal by the first quarter of 2016 ;

ii. During the second half of 2010 and the first half of 2011, market participants had expected that the passive runoff of LSAP assets (i.e., the FOMC stops re-investing the principal payments from matured LSAP securities) would occur at "some point in 2012," and the sell-off would begin in early 2013 and would take five years to finish, as reflected in the Survey of Primary Dealers during this period;

iii. Since the FOMC explicitly announced its "exit principle" in June 2011 and the sequencing of federal funds rate "lift-off" and the LSAP unwinding steps, I assume that the market participants have expected that the passive runoff of LSAP assets would begin six months prior to the "lift-off" and the active sell-off would begin nine months after the "lift-off," and the sell-off would take five years to finish.

3) Unless the FOMC explicitly announces a new purchasing plan, I assume that the market participants do not expect any new purchases beyond the ones that have already been announced. Of course, prior to any FOMC announcement, it is possible that market participants might have already anticipated some changes to the existing plan. However, market information regarding such views is sparse and very unreliable. Therefore, a conservative approach seems more appropriate here and I assume that market participants do not anticipate any new purchases until the FOMC makes the announcement.

4) Survey results on the future path of the SOMA balance size come with a range, and the median responses of the surveyed projections are used in constructing the LSAP measures.

Once the market projections of future SOMA balance paths are obtained, the next step is to calculate the LSAP measure, defined as the present discounted value of the excess-SOMAbalance-to-potential-GDP ratio at each point of time $t$, excluding the holdings of Treasury bills

$$
L S A P_{t}=\sum_{i=0}^{\infty} \beta^{i} E_{t}\left(\frac{S O M A_{t+i}}{G D P_{t+i}^{P O T}}-\mu\right)
$$

where $S O M A_{t}$ is the SOMA balance excluding holdings of Treasury bills, $G D P_{t}^{P O T}$ the Congressional Budget Office's estimates of potential nominal GDP, and $\mu$ the average of SOMA-topotential-GDP ratio from 2003 to 2008 (3.94 percent). $\beta$ is a time discount factor set to equal 0.9967 so that the implied annualized discount rate is $4 \%$ (choosing a different value implies almost no changes to the estimated magnitude of the LSAP effect). The LSAP measure is normalized so that a reading of 100 percent is equivalent to an average excess SOMA balance of 100 percent of potential GDP for the period of a year.

(C)International Monetary Fund. Not for Redistribution 
The $L S A P^{N}$ measure is constructed in a similar fashion, except that at each point of time, I assume that market participants do not update the expected length of the holding period of the LSAP assets that have already been purchased. For instance, after the completion of QE I purchases in March 2010, even if market participants have gradually updated their expectations of the unloading schedule of all LSAP assets, I assume that the market participants will only update their expectations of the length of the holding period for assets to be purchased going forward, but not the QE I assets, i.e., the "forward guidance" after March 2010 does not affect market projections of the unloading schedule of QE I assets. Therefore, the $L S A P^{N}$ measure only captures the effects of asset purchases per se, but is not affected by the Fed's "forward guidance" over time, and the difference between $L S A P$ and $L S A P^{N}$ captures the influences of "forward guidance" in extending the holding period of purchased LSAP assets. 


\section{Table A1: Key LSAP Announcements: November 2008 to September 2013}

November 25, 2008: The Federal Reserve announced that it would initiate a program to purchase up to $\$ 500$ billion mortgage-backed securities (MBS) and up to $\$ 100$ billion governmentsponsored enterprises (GSE) direct obligations. The purchases would begin "before year-end," and the purchases are expected to take place over several quarters."

December 16, 2008: The FOMC indicated that "it stands ready to expand its purchases of agency debt and mortgage-backed securities as conditions warrant. The Committee is also evaluating the potential benefits of purchasing longer-term Treasury securities."

March 18, 2009: The FOMC announced that it would "increase the size of the Federal Reserve's balance sheet further by purchasing up to an additional $\$ 750$ billion of agency mortgagebacked securities, bringing its total purchases of these securities to up to $\$ 1.25$ trillion this year, and to increase its purchases of agency debt this year by up to $\$ 100$ billion to a total of up to $\$ 200$ billion. Moreover, to help improve conditions in private credit markets, the Committee decided to purchase up to $\$ 300$ billion of longer-term Treasury securities over the next six months."

August 12, 2009: The FOMC eliminated the "up to" phrase in its intended purchase amount of Treasury securities. It also stated that it would slow the pace of these transactions and anticipates that the full amount will be purchased by the end of October."

September 23, 2009: The FOMC eliminated the "up to" phrase in its intended purchase amount of the MBS, as well as its plan to "slow the pace of these purchases in order to promote a smooth transition in markets and anticipates that they will be executed by the end of the first quarter of 2010."

November 4, 2009: The FOMC clarified that the intended purchase amount of agency debt would be $\$ 175$ billion, instead of the previously announced "up to $\$ 200$ billion."

August 10, 2010: The FOMC announced that it "will keep constant the Federal Reserve's holdings of securities at their current level by reinvesting principal payments from agency debt and agency mortgage-backed securities in longer-term Treasury securities. The Committee will continue to roll over the Federal Reserve's holdings of Treasury securities as they mature."

November 3, 2010: The FOMC announced that it "intends to purchase a further $\$ 600$ billion of longer-term Treasury securities by the end of the second quarter of 2011 , a pace of about $\$ 75$ billion per month."

CInternational Monetary Fund. Not for Redistribution 
September 21, 2011: The FOMC announced that it "intends to purchase, by the end of June 2012, $\$ 400$ billion of Treasury securities with remaining maturities of 6 years to 30 years and to sell an equal amount of Treasury securities with remaining maturities of 3 years or less."

June 20, 2012: The FOMC announced its intention "to continue through the end of the year its program to extend the average maturity of its holdings of securities."

September 13, 2012: The FOMC announced that it plans to "increase policy accommodation by purchasing additional agency mortgage-backed securities at a pace of $\$ 40$ billion per month."

December 12, 2012: The FOMC announced that it "will continue purchasing additional agency mortgage-backed securities at a pace of $\$ 40$ billion per month. The Committee also will purchase longer-term Treasury securities after its program to extend the average maturity of its holdings of Treasury securities is completed at the end of the year, initially at a pace of $\$ 45$ billion per month."

September 18, 2013: The FOMC decided to "continue purchasing additional agency mortgagebacked securities at a pace of $\$ 40$ billion per month and longer-term Treasury securities at a pace of $\$ 45$ billion per month." 